F. med. Genet. (1968). 5, 137.

\title{
Inherited Diseases of the Inner Ear in Man in the Light of Studies on the Mouse
}

\author{
M. S. DEOL \\ From Medical Research Council, Experimental Genetics Research Unit, University College, London
}

Disorders of the inner ear, occurring by themselves or in association with abnormalities of other structures, are quite common in man. The hereditary nature of a number of them has been recognized for long, and several good reviews on the subject have been written. One of the latest and most comprehensive is by Fraser (1964a), who has also provided an excellent historical background. But it has always proved difficult to speculate about the manner of origin of these disorders or the factors participating in their genesis. Even information on their pathology is far from copious. The difficulty arises from many sources. For any reliable study of a disorder the inner ear must be fixed without delay after death, which is not always easy to arrange. Moreover, a fairly large sample is required to form a moderately accurate picture of the range of abnormalities attributable to a particular gene. In the case of congenital disorders suitable embryonic material is needed before any interpretation can be ventured upon, and this serves to multiply the difficulties. Further, it is not always possible to decide whether the same or a different gene is operating in two families with apparently similar abnormalities, tests for allelism being virtually out of the question in man. Most genes are sensitive to changes in their genetic background, and the pitfalls of assuming the identity of two genes on the basis of similarities of their effects, or the lack of identity on the basis of differences, need not be emphasized. Another potent source of difficulties is the fact that defects of hearing are usually so striking that attention is concentrated on the cochlea at the cost of the vestibular part of the labyrinth. In many instances no information whatever is available concerning the vestibular part, which makes the hypotheses offered questionable, if not futile.

In view of this it is astonishing that no good use has been made so far of mutant mice with abnormalities of the inner ear for illuminating human diseases. Investigation of the mouse suffers from none of the disabilities mentioned above. Over 30 different genes are known to affect the inner ear and their manner of transmission is well understood. In the majority of cases detailed information on pathology and development is available. Above all, there are a number of fundamental similarities between inherited diseases of the inner ear in man and in mouse. The pathological features in many cases are remarkably alike. There is the same tendency for the ear to be affected in association with certain other structures. In both species the dominant genes often have incomplete penetrance. The major difference is the occurrence of a characteristic type of behaviour in the mouse known as the waltzing syndrome. But this may well be founded on a neurological feature which is peculiar to rodents or is subservient to other features in higher organisms.

Fraser (1964a) suggests that human studies have several advantages over those of animals because relatively more is known of human physiology, biochemistry, and morbid anatomy. This opinion is open to dispute. For example, it is certainly not true of morbid anatomy. In the mouse serial sections of an abnormal cochlea and labyrinthine apparatus permit of precise identification of abnormal changes, even very small ones. In man the temporal bone is so large, relative to the inner ear and associated structures, that preparation of material for examination almost invariably affects micro-structure. Further, a few minutes delay after death makes the preparation of perfect specimens impossible. It should be noted also that the earliest biochemical studies of the cochlea and labyrinthine fluids were carried out on animals.

Another type of animal study that can shed light on congenital disorders in man is transplantation experiments on amphibian and avian embryos. A great deal has been learnt from this work about factors governing the morphogenesis and differentiation of the inner ear, yet they have largely been ignored or only vaguely referred to in attempts at interpreting human malformations. No effort 
has been made so far to incorporate them into a coherent scheme covering the majority, if not all, of the congenital abnormalities.

It would not serve any useful purpose to give a comprehensive list of references on the literature of deafness in man. Other authors, notably Fraser (1964a), McKusick (1966), and Ormerod (1960), have dealt with this aspect, and the reader is referred to them. Work on mouse mutants will be dealt with more fully, for it has not been reviewed for a considerable time, but even there only important papers will be mentioned. Further references may be found in Grüneberg (1952) and Sidman, Green, and Appel (1965).

\section{I: INHERITED DISEASES OF THE INNER EAR IN MAN}

In the absence of any developmental studies there is no satisfactory way of arranging the large number of inherited diseases of the inner ear in man into categories.

Grouping by mode of inheritance, whether autosomal recessive or dominant, or X-linked recessive, though useful, is, at best, only a preliminary step towards defining aetiology. Conditions clinically homogeneous may be heterogeneous as judged by mode of inheritance. The classification adopted here, according to whether a disease is congenital or with late onset, is also far from satisfactory. But it has a moderate advantage in that the congenital conditions are more likely to be morphogenetic and the others are more likely to be degenerative. Some of the abnormalities described as congenital may possibly have come into being in early infancy, for according to most reports. the diagnoses were carried out in later life. Moreover, conventionally the term deafness does not exclude the presence of some residual response to sound. It only signifies that hearing ability is so poor that hearing aids are useless. It will be noticed that virtually all diseases mentioned involve the sense of hearing, but there can be little doubt that disorders of the vestibular part occur without the involvement of the cochlea. Because of having no striking effect on behaviour they remain unnoticed unless tests are carried out for their detection (Everberg, 1955, 1957, 1960a, b, c).

\section{I.1: Congenital Diseases}

The majority of all cases of perceptive deafness identified at birth or at least when defect of hearing is first detected, are not parts of syndromes (whether or not genetically determined) with detectable anomalies of other systems. The sizes of estimates of the proportion of deaf individuals whose deafness is part of a syndrome will depend on the criteria of acceptance as deaf. In a majority of the syndromes where other systems are affected the deafness is partial.

There is no doubt that a considerable proportion of those with severe congenital deafness have symptomatic disturbance of the labyrinth and other parts of the central nervous system. Although it is difficult adequately to assess the real or potential intelligence of deaf mutes, there can be little doubt that an undue proportion of deaf mutes are also mentally defective. It is also clear that neither disturbed labyrinthic function nor disturbance of other parts of the central nervous system are confined to monogenic traits or to conditions where there is no evidence of genetic determination.

Deafness in Association with Abnormalities of Eyes. Deafness associated with retinitis pigmentosa is the distinguishing feature of Usher's syndrome, which is not only one of the longest known genetical entities of its kind, but also one of the commonest. Its manner of inheritance is autosomal recessive. Although cases have been reported since the middle of the 19th century the first definitive account was given by Usher in 1914 . Since then a large number of cases from many countries have been described, two of the most thorough surveys being that of Lindenov (1945) in Denmark and Hallgren (1959) in Sweden. Both these authors put the incidence of the syndrome in their populations at about 3 in 100,000. Vestibular disturbances are said by some authors to be commoner in Usher's syndrome than in any other form of deafness (Steinberg, 1937; Arnvig, 1955).

The evidence as to whether there are real differences in frequency of Usher's syndrome in different communities is inconclusive. The intensity of ascertainment and standards of ophthalmology are unlikely to have been the same in all studies.

A number of other syndromes have also been reported which resemble Usher's syndrome in some ways and differ in others. The question of their genetical relationship with Usher's syndrome has been examined by Fraser (1964a), who has also listed all reports available until then. To his list may be added two recent papers. Lang (1959) has described a family in which the parents were first cousins, and 5 out of 10 children had Usher's syndrome. Kloepfer, Laguaite, and Mclaurin (1966) examined 468 persons with hearing loss in a 
French Cajun community in Louisiana and discovered that 158 of them had retinitis pigmentosa and other anomalies of the eyes.

Deafness in Association with Abnormalities of the Thyroid. Deafness associated with goitre occurs in Pendred's (1896) syndrome. The inheritance is usually recessive (Brain, 1927; Fraser, 1965a; Fraser, Morgans, and Trotter, 1960), though Johnsen (1958) has produced some evidence favouring semi-dominance. Thyroxine synthesis is affected, the subjects being usually euthyroid and only occasionally hypothyroid. Deafness is not secondary to the thyroid abnormality, but is an independent effect of the gene. In some cases mental defect bordering on cretinism occurs. For this reason in early days it was sometimes confused with goitrous cretinism, in which absence of speech development results from mental defect and not deafness. Batsakis and Nishiyama (1962) have estimated that it accounts for $1-10 \%$ of all hereditary deafness. Fraser (1965a) in his exhaustive survey of this disease in the British Isles has put its frequency at $7 \cdot 5$ cases per 100,000 births. There is a possibility that there may be two genetically distinct varieties of this syndrome, because the results of biochemical studies by Fraser et al. (1960) differ considerably from those by Hollander et al. (1964).

Deafness in Association with Abnormalities of the Heart. Deafness associated with abnormalities of the heart occurs in Jervell and LangeNielsen's (1957) syndrome. A rare disease, first described in a Norwegian family, it has since been reported from many other parts of the world. Affected persons suffer from deafness and fainting attacks, which may result in sudden death. In addition they have a peculiar abnormality of the electrocardiogram, the Q-T interval being much prolonged. Fraser, Frogatt, and Murphy (1964b) put its incidence at 1 in 100,000 births. Many cases have been uncovered from among deaf persons by screening for the electrocardiogram peculiarity (Fraser, Froggatt, and James, 1964a; Fraser et al., 1964b). Post-mortem examination has failed to provide any clue to the fainting attacks or to the association between deafness and other abnormalities. It is possible that the syndrome sometimes occurs without deafness, but the evidence in support of this view is not strong. The inheritance is recessive.

Congenital deafness and abnormalities of the heart are also associated in pulmonary stenosis. Lewis et al. (1958) have described a family in which the mother and 3 of the 5 children were affected.
They accepted the possibility that two genes might be involved, but a single gene view is supported by the report of another family by Koroxenidis et al. (1966) in which the mother and 4 of the 8 children were similarly affected.

Deafness in Association with Abnormalities of Pigmentation. Deafness in association with pigmentary abnormalities occurs in a number of diseases forming a group. The best known of all is Waardenburg's syndrome (Waardenburg, 1951; Arnvig, 1959; Zelig, 1961) which is inherited in the dominant manner. Deafness in this syndrome may be unilateral or bilateral and even in the bilateral type some residual hearing is often present. Other features are a wide nose bridge, lateral displacement of the inner canthus, confluence of the eyebrows, heterochromia of the irides, and white patches in the hair. Of these, the abnormalities of the canthus are the most constant, and the white forelock the least. Waardenburg's original survey was carried out in Holland and for some time the syndrome was thought to be peculiar to people of Dutch origin, but there have been a number of reports from other countries in recent years. Fisch (1959) and Fraser (1964b) have found that it is by no means rare in the British Isles. Settelmayer and Hogan (1961) have described an affected American family with no Dutch connexions, and Hansen, Ackaouy, and Crump (1965) have described an affected Negro family. It has also been reported to occur among the Maoris in New Zealand (Houghton, 1964), though in this case there is no evidence as to its inheritance. According to Fisch (1959), when some residual hearing is present the performance is better for higher frequencies than for lower ones.

A different syndrome, also with dominant inheritance but with the possibility of sex-linkage open, has been described by Tietz (1963) in a large family: 14 affected persons were found in 6 generations. Instead of the white forelock of Waardenburg's syndrome the entire skin and hair were unpigmented. There is clear evidence that it is not a case of albinism but hypopigmentation (the difference will be discussed later in connexion with mouse mutants), for pigment is present in the eyes. The abnormalities of the canthus and the nose, which form the distinguishing features of Waardenburg's syndrome, are absent. Intelligence is not much affected. Deafness is of the order of about 100 decibel loss.

A recessive form of total hypopigmentation associated with deafness has been described by Ziprkowski and Adam (1964). Only two subjects 
were examined, but the family was large and the existence of other cases among close relatives was reliably reported.

A recessive sex-linked form of deafness associated with pigmentary anomalies is also known to exist. A large Israeli family of Moroccan origin has been described by Margolis (1962) and by Ziprkowski et al. (1962). The absence of pigment in the skin is not total, for small pigmented spots may be found scattered all over the body. The vestibular part of the labyrinth is known to be affected as well. Sometimes a little hearing is present.

\section{Deafness in Association with Abnormalities} of Other Structures. Deafness has often been reported to occur in association with abnormalities of many other structures, but cases of any particular kind have not been numerous enough for the condition to be recognized as a syndrome. For the same reason it is impossible to be reasonably certain whether all symptoms are caused by one gene or more. Probably the best example is the association of deafness with abnormalities of hands and feet, which has been the subject of several reports, one of the most recent being by Wildervanck (1963). Feinmesser and Zelig (1961) have described a family with deafness and dystrophy or absence of nails. Some hearing was left, and caloric and rotation tests showed that the vestibular part was also affected. Latham and Munro (1937) have reported a family with deafness and myoclonic epilepsy, the condition being inherited in the recessive manner. Deafness also sometimes forms a part of Hunter's syndrome (McKusick, 1966).

Deafness Not Known to be Associated with Other Abnormalities. A high proportion of all severe deafness present at or shortly after birth is of this type. In about $90 \%$ of cases it appears to be caused by one of a large number of autosomal recessive genes, though how many are involved is a matter of dispute. Stevenson and Cheeseman (1956) showed that, in Northern Ireland, $9 \%$ of unaffected parents of uncomplicated deaf mutes were consanguineous, and produced several pedigrees where recessive deaf mutes had married and had only normal children. This finding was confirmed by Deraemaeker (1960). Chung, Robison, and Morton (1959), analysing the Northern Ireland data, suggested that there might be as many as a hundred different recessive genes that determined deaf mutism segregating in that relatively small community. Slatis (1958) suggested that deafness was sometimes the result of simultaneous heterozygosity $\Omega$ for two or more independent genes, but Chung et al. $\frac{\Phi}{\triangle}$ (1959) rejected this explanation. (See III.3.)

Dow and Poynter (1930) described a large family $\overrightarrow{\vec{F}}$ where the transmission appeared to be X-linked, $\stackrel{?}{?}$ and Mitsuda, Inoue, and Kazama (1952), Deraemaeker (1958), Richards (1963), and Parker (1958) $\frac{\bar{\sigma}}{\bar{\omega}}$. have described similar families where the evidence $\frac{\overrightarrow{ }}{\sigma}$ for X-linked transmission was strong. In Parker's $\cong$ family an affected female was probably the offspring क of an incestuous union such that she could have been $\overrightarrow{0}$ homozygous for the gene. Hearing loss in Parker's family was not complete, though over $70 \%$, and $\vec{\sigma}$ greater at high frequencies. Vestibular function in this family was not abnormal.

Fraser (1965b) has reported a number of families or and re-analysed the data of Hopkins and Guilder (1949) and Stevenson and Cheeseman (1956). He estimated that in $6.2 \%$ of severely affected males the $ᄋ$ condition was X-linked and that the over-all fre- quency of X-linked deafness was as high as 1.5 per $c$ million births. Chung et al. (1959) estimated a rather lower frequency.

There is no doubt that a small percentage of cases of uncomplicated deafness is determined by autosomal dominant genes. In a majority of cases, however, the deafness is partial and many cases of early onset progressive high-tone deafness are inherited in this way.

At one time there was some doubt concerning the presence of dominant autosomal genes causing deafness, but Fraser (1964c) has argued strongly in their favour, with the aid of several examples. Dominant autosomal genes with incomplete penetrance are almost certainly responsible for at least some cases of unilateral abnormalities of the inner ear. Smith's (1939) report on unilateral hereditary deafness may well have concerned cases of Waardenburg's syndrome, as pointed out by Fraser (1964a), but Everberg's (1955, 1957, 1960a, b, c) data have established unilateral deafness as an independent entity beyond doubt. Having observed it in identical twins and three other families (Everberg, 1955, 1957), he carried out a comprehensive survey of all children in Copenhagen municipal schools, and discovered that at least 1000 of them were deaf on one side. He further investigated 122 cases taken at random from among them, and found that the condition was inherited in about $25 \%$. The vestibular part was not functioning in the deaf ear in $28 \%$ of cases, but was normal in others. Abnormalities of the labyrinth were seen by $x$-ray examination in only $18 \%$ of cases. The condition always appeared to be transmitted by a dominant gene with incomplete penetrance. 
Pathology of Inner Ear. The pathology of the inner ear in congenital diseases has been the subject of numerous studies and the published material has recently been reviewed by Ormerod (1960). Virtually all abnormalities described are defects of morphogenesis and differentiation, which have been classified by Ormerod into five categories in a descending order of severity. The categories have been named after the authors of first reports in which the abnormality concerned had been described.

The severest type of defect is known as the Michel type. In this case there is either no inner ear at all and the petrous part of the temporal bone is lacking, or the bone is present and the place of the inner ear is occupied by cavities bearing no resemblance to any known structure. Abnormalities of other organs and mental retardation are often present. The next class is Mondini-Alexander type. In this case though the inner ear is present and the cochlear and vestibular divisions can be identified, the whole organ is grossly malformed. The cochlear tube is usually poorly coiled, and the semicircular canals may be solid bony structures without any lumen. Some sensory epithelium may be formed in various places. The two ears are frequently quite different. The third class is Bing-Siebenmann type, in which the development of the inner ear is more advanced, but no part can as yet be described as normal. The sensory epithelium, though identifiable, is immature. It is often associated with anomalies of the eyes and mental defect. The fourth class is Scheibe type. In this case the abnormalities are confined to the cochlea and the saccule, the remaining parts being largely normal. In the cochlea the differentiation of the contents of the scala media is poor. The tectorial membrane is distorted and Reissener's membrane may be found adhering to the stria vascularis, the organ of Corti, and the tectorial membrane, so that the cavity of the scala media is obliterated. In some cases, on the other hand, the very opposite happens, Reissner's membrane being enlarged and flaccid, and the cavity greatly dilated. The stria vascularis is poorly developed. In the saccule the free wall may be in contact with the macula, and the sensory epithelium is not well differentiated. The last class is Siebenmann type, in which the inner ear is only rarely involved, there being some degeneration of the organ of Corti or even a closure or distension of the scala media.

In inherited diseases of the inner ear the Scheibe type abnormalities have been observed most frequently. The Mondini-Alexander type is less common, and the remaining three types are rare.
The Scheibe type abnormality is also known to occur in association with pigmentary defects. In most reports dealing with this class there are references to lack or reduction of pigment in various structures. Fisch (1959) examined the inner ear in one case of Waardenburg's syndrome and found that the pathology was of Scheibe type.

Everberg (1960a, b) has described gross abnormalities of the inner ear as observed by $x$-ray examination in cases of unilateral deafness. Broadly speaking they are of two types. In the first, the abnormalities are largely confined to the semicircular canals which may either be closed throughout or have their lumen obliterated over a small area. In the second, the vestibule and the lateral semicircular canal form a single large cavity. The cochlea may be absent and the superior canal partially obliterated in addition. In two cases the whole labyrinth seems to have been represented by one large cavity. Everberg also examined the Ibsen-Mackeprang collection in Copenhagen of temporal bones of deaf mutes, and found similar abnormalities there. The deaf-mutism in several cases was known to be of genetic origin.

\section{I.2: Diseases with Late Onset}

As with congenital disorders, the diseases with late onset usually occur in association with other abnormalities. In some the involvement of the inner ear may well be secondary, but in others it appears to be so unrelated to the associated anomalies that it is probably an independent effect of the gene. The deafness may be progressive or not progressive. On account of the comparative rarity of these diseases this group is of much less practical importance.

Deafness with late onset quite commonly forms a part of Alport's syndrome (Dubach and Gsell, 1962). Usually, though not always, of the progressive type, it is associated with haematuria. A large number of families segregating for this syndrome have been described and the literature has been reviewed by Shaw and Glover (1961) and Cohen, Cassady, and Hanna (1961). Males are on the whole more severely affected than females. There is a considerable disagreement of opinion regarding the manner of inheritance: at one time it was believed to be partially sex-linked, but is now treated as an autosomal dominant with incomplete penetrance. Shaw and Glover (1961) have explained certain peculiarities of the inheritance of this gene by supposing that in the male the autosome bearing the gene shows a preference for segregation with the $\mathrm{X}$ chromosome. Other important reports not given in the reviews mentioned above are by 
Whalen et al. (1961), Williamson (1961), and Mulrow et al. (1963).

A different type of abnormality of the kidneys with progressive deafness has been reported by Herrmann, Aguilar, and Sacks (1964) in a family with 14 affected members in 5 generations. There was a mild diabetes mellitus and light epileptic type seizures. Necropsy showed vacuolated renal tubes and widespread neuronal degeneration in the brain. The authors think that only one dominant gene with incomplete penetrance was involved. Another form of kidney abnormality has been found to occur with progressive deafness (Muckle and Wells, 1962). Nine members of a family covering 5 generations were affected. Necropsy revealed degeneration and amyloid infiltration of the kidneys in addition to degeneration of the organ of Corti and the cochlear nerve. The manner of inheritance appears to be dominant.

Progressive deafness with late onset also occurs in Norrie's disease. Warburg $(1961,1963)$ has described two large families, and rediscovered many earlier reported cases. It is associated with various abnormalities of the eyes, such as microphthalmia, retinal hyperplasia, and opacities of all kinds. Low mental capacity is also a common feature of affected persons. It is transmitted by a sex-linked recessive gene.

A similar combination of abnormalities of the eyes and progressive deafness occurs in FlynnAird's syndrome (Flynn and Aird, 1965). In a family of 68 members 15 persons in 5 generations were found to be affected, all having bilateral perceptive deafness and severe myopia. Retinitis pigmentosa and dementia also occurred in some. Deafness usually appeared in the second decade, but in one case as early as the 7th year. Necropsies showed the brain to be atrophic in at least 3 cases. A single dominant gene is believed to be responsible for the syndrome. The authors consider the possibility that some other syndromes described earlier may in fact be the same.

The association of late deafness with abnormalities of the skin and other structures of ectodermal origin has been reported by Helweg-Larsen and Ludvigsen (1946) and Marshall (1958). A severe reduction in the number of sweat glands is the most constant feature, but malformations of the nails and teeth are quite common, and the eyes are sometimes affected. Marshall thinks that deafness may be congenital or appear early in life, but the other authors say it becomes apparent between the ages of 35 and 45 years.

Abnormalities of several other structures have been reported to occur with late deafness, but as the number of affected persons is small the question of $\Omega$

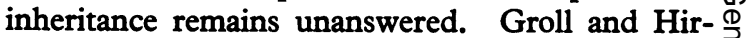
schowitz (1966) have described the association of $\stackrel{\Phi}{+}$ deafness with steatorrhoea in one family, and Hicks $\vec{\Rightarrow}$ (1922) has reported a similar combination with $\stackrel{?}{+}$ sensory radicular neuropathy. One member of $\frac{}{c}$ this latter family, in whom deafness had appeared at $\frac{\bar{\sigma}}{\bar{N}}$ 40 and had become total at 53, was later examined by Denny-Brown (1951): at necropsy the brain $\stackrel{\AA}{2}$ was considerably reduced and there was widespread के loss of ganglion cells.

Late deafness not associated with any other obvious abnormality has been described by Mohr and Mageröy (1960). A large family had 11 affected members, all males, covering 3 generations. The inheritance is sex-linked, but it is believed to be different from other sex-linked types of deafness in that it is progressive and appears late enough to allow speech to develop. Richards (1963) has pointed out that it might be a case of sex-limited rather than sex-linked inheritance.

Another form of uncomplicated late deafness has been mentioned by Dolowitz and Stephens (1961), who studied a family of 349 members covering 6 generations for a period of 14 years: 71 adults had impairment of hearing. In addition, 20 children had high tone loss which they thought was the early stage of the defect. An autosomal dominant gene with complete penetrance is thought to be responsible.

\section{II: GENES AFFECTING THE INNER EAR IN THE MOUSE}

Nearly 30 genes are known to affect the inner ear in the mouse, and several more are believed to do so because of the behaviour of the mutant animals (for these see Sidman et al., 1965). Again there is no really satisfactory way of classifying them, for though most of the mutants have been subjects of histological and embryological studies, the mechanism of gene action is understood to some extent in only a few of them. The arrangement used by Grüneberg (1956), which is based on the nature of the effects, whether morphogenetic or degenerative, or both at once, has been adopted here. It has the merit of distinguishing between genes acting in embryonic life and those acting later. Gene symbols are given in brackets after the name. [The gene shaker-short (st; Dunn, 1934; Bonnevie, 1936) has been left out because it is no longer in existence.]

The vast majority of mutants in all three groups share a peculiarity of behaviour commonly known as the waltzing syndrome. The animals are characterized by a tendency to run in circles, jerking 
movements of the head in the vertical plane, hyperactivity, impairment of the ability to swim, and abnormal responses to linear and angular accelerations. In the following descriptions it is simply referred to as the shaker-waltzer type behaviour, with attention being drawn to any deviations from the general pattern.

\section{II.1: Genes with Morphogenetic Effects}

There are 12 genes in this group. Some of them affect the entire ear and others only a small part of it. They are arranged in a descending order of severity, as far as it is possible to make distinctions of this type.

(i) Kreisler (kr). This recessive mutation, probably induced by radiation, was first described by Hertwig (1942a, b). The homozygotes are deaf and have typical shaker-waltzer type behaviour, which becomes apparent during the second week of life. Malformations of the inner ear are the severest of all mutants and extremely variable (Hertwig, 1944, 1956; Deol, 1964a). Hardly any two ears are alike in detail. In some cases the inner ear is just a group of formless cavities with or without interconnecting passages, no part bearing any resemblance to any structures in the normal inner ear. In others the cochlea, the saccule, the utricle, some semicircular canals, and even an endolymphatic duct, all rudimentary or otherwise abnormal but recognizable as such, may be present. The commonest type of ear is usually in between these two extremes. Sensory epithelium of various degrees of maturity may be found in patches of different sizes, sometimes only a few cells large, scattered without any regard to its normal position. The acoustic ganglion is greatly reduced and often occurs in anomalous positions; it seldom divides into its usual constituents. The position of the facial and glossopharyngeal ganglia is also frequently disturbed, and their size is reduced. The auditory capsule is malformed and sometimes incomplete. When this happens the inner ear grows out of the gap in the form of a cyst. If the gap is medial the cyst protrudes into the cranium for a considerable distance, interfering with the growth of the brain in that part and seriously disturbing the position of the nerves in the way. Sometimes it fuses with the brain, and the neural epithelium may be seen covering a small part of the brain surface. If the gap is lateral the cyst grows into the muscles below and behind the ear; the cells of the acoustic and facial ganglia are sometimes seen scattered along its thin walls, which may also provide pathways for widely spread-out fibres of the acoustic and facial nerves.

Developmental studies have shown that the Kreisler inner ear is abnormal almost from the very beginning (Hertwig, 1944; Deol, 1964a). Even when the otic vesicle is just a shallow bowl it can be seen to occupy an abnormal position in relation to the neural tube, and the neural tube itself is also abnormal; the last three neuro- meres in the rhombencephalon, from the 4th to the 6th, do not develop, their place being taken by a large composite neuromere. The facial-acoustic ganglionic complex does not keep to its normal position in the region of the 4th neuromere anterior to the otic vesicle, but spreads posteriorly along the neural tube and merges into the glossopharyngeal-vagal complex, effectively separating the neural tube from the otic vesicle. In addition, its cells do not form a well-organized mass but have a strong tendency to trail off into the surrounding tissue. The subsequent development of the otic vesicle takes place without any coherent underlying plan and results in the abnormalities described above. These abnormalities can be shown to be the direct consequence of the separation of the otic vesicle from the neural tube and of the abnormal position and the lack of organization of the ganglia. (See III.2.)

(ii) Dreher (dr). This recessive gene arose as a spontaneous mutation, and was first described by Falconer and Sierts-Roth (1951). The homozygotes are deaf and have typical shaker-waltzer type behaviour. There is some tendency to hold the head tilted to one side, especially in the young. Malformations of the inner ear are much less severe than in the majority of kreisler mice (Fischer, 1956, 1957). They are also much less variable. The endolymphatic duct is rudimentary or dilated and the sac does not reach its normal position. The cochlear tube is reduced and loosely coiled. The scala media merges into the saccule without the aid of a ductus reuniens. The separation of the saccule and the utricle is similarly imperfect. The semicircular canals. though formed, may be short and dilated. The neural epithelium remains clearly immature in the cochlea. Elsewhere it appears to differentiate better.

Fischer (1958) studied the development of this mutant and found that the first signs of an abnormality appeared at the late 10-day stage, when the growth of Anson's fold separating the utricle and the saccule was clearly retarded. Deol (1964b) examined the neural tube and discovered that abnormalities of this structure in the rhombencephalon preceded those of the inner ear by almost 2 days. The thin, kite-shaped roof of the rhombencephalon does not extend far enough posteriorly, and the thick walls meet above in the region of the inner ear. It has been argued that the malformations of the inner ear are consequent on this abnormality of the neural tube. (See III.2.)

(iii) Shaker-with-syndactylism (sy). This recessive mutation, first described by Hertwig (1942a, 1942b), was induced by radiation. The homozygotes, which seldom live longer than about 6 weeks, are deaf. The behaviour is of the shaker-waltzer type, but not so marked as in other mutants. In addition to the malformations of the inner ear, syndactylism occurs in the hind feet (occasionally the front feet are also affected), and the ossification is faulty in the whole skeleton (Grüneberg, 1963). The inner ear is abnormal throughout (Hertwig, 1951, 1956; Deol, 1963). In the cochlea all the contents of the scala media are affected. The 
tectorial membrane is thick and distorted; the organ of Corti is poorly differentiated; the stria vascularis may be too thin, or so thick that it bulges out into the scala. Reissner's membrane is sometimes seen adhering to the tectorial membrane, the organ of Corti, and even the stria vasculatis, to the virtual elimination of the scala media (Fig. 1). In other cases it is much enlarged and flaccid, and the scala media is greatly dilated. The saccule is much smaller than normal. Its free wall is mostly in contact with the macula, to the virtual obliteration of the saccular cavity (Fig. 2). The otolith mass is often broken up and scattered in between layers of undifferentiated cells. In some places the neural epithelium dedifferentiates and its cells migrate into the cellular mass filling the cavity. Similar changes take place in the utricle. The semicircular canals grow narrower and narrower until their lumen is eliminated along most of their length. The cristae are severely affected, with very few normal cells in the neural epithelium. There are indications that the brain is not normal.

The first signs of abnormality appear in 13-day embryos when all parts of the labyrinth are already clearly recognizable. The mesenchymal layer separating the utricle and the saccule is abnormally thick, and these two structures lose contact as a result. For a considerable time after this the visible abnormalities remain confined to the periotic structures derived from the mesenchymal condensations. It is possible that these are in some way responsible for the later malformations of the otic labyrinth, though it is equally possible that the periotic abnormalities themselves are an indication that the otic labyrinth is not quite normal, for the otic labyrinth is known to govern the congregation of mesenchymal cells around it. The exact relation between the two is not clear.

(iv) Kinky (Fuki). This semi-dominant gene, lethal in the homozygous condition, was first described by Caspari and David (1940). It is primarily known for its effects on the axial skeleton, which are invariably present. As far as the inner ear is concerned its penetrance is always incomplete, the degree of penetrance differing from stock to stock, being probably dependent on the genetic background. The affected animals may or may not be deaf. Their behaviour varies from a slight tendency to run in circles to the full manifestation of the shaker-waltzer syndrome. Some animals hold their heads tilted to one side. The malformations of the inner ear, which are not always seen in affected animals, are extremely variable, and there is no obvious correlation between the two sides (Deol, 1966b). The cochlea is frequently normal. When not, the cochlear tube is short and poorly coiled and its contents not well differentiated, though even in such cases the organ of Corti may reach sufficient maturity in a small area to allow some hearing to develop. The abnormalities of the saccule and the utricle follow roughly the same pattern as in the mutant shaker-with-syndactylism. The semicircular canals, when affected, are either short and extremely wide, or narrow and occluded in places. The differentiation of the neural epithelium in the cristae is poor. The endolymphatic duct and sac are frequently extraordinarily dilated and may be confined within the otic capsule. The development of the mutant has not been studied so far.

Fused ( $F u$; Reed, 1937; Dunn and Gluecksohn-Waelsch, 1954), an allele of kinky, has similar effects on behaviour. It is believed to affect the inner ear, though this has not been investigated.

(v) Dancer (Dc). This gene was described by Deol and Lane (1966), who also studied the pathology and development of the mutant animals. It is semidominant, with incomplete penetrance. The homozygotes die at birth, if not earlier, on account of severe malformations, including cleft palate. The heterozygotes have normal hearing. The behaviour is of the shaker-waltzer type, but of variable intensity. Most animals have a white spot in the middle of the head. The abnormalities of the inner ear are confined to the vestibular part. The saccule is a little reduced, but otherwise normal. The utricle is small and distorted, and its macula is never present. The superior and lateral semicircular canals are frequently constricted or closed near their proximal ends, and their cristae either missing or only rudimentary. The two sides are often asymmetrical in this respect. The posterior canal is unaffected. The superior vestibular ganglion is grossly reduced, if not altogether lacking.

All these abnormalities have been traced back to a reduction of the acoustic ganglion which can be seen as early as the 10-day stage, before the otic vesicle begins to differentiate. A day later it becomes clear that the missing part corresponds to the superior vestibular ganglion. The nerves normally originating from it are not formed, and the neural epithelium in the corresponding regions does not develop. (See III.2.)

(vi) Twirler (Tw). A semi-dominant gene, with incomplete penetrance, it was first described by Lyon (1958). The homozygotes die soon after birth. The heterozygotes can hear. Their behaviour is of the shaker-waltzer type in general, but the movements of the head may occur in the horizontal plane as well as in the vertical. The most constant abnormalities of the inner ear are the reduction or absence of the lateral semicircular canal and the absence of the otoliths in the maculae. The other two canals may also be slightly irregular in shape. The abnormalities are often asymmetrical. Twirler mice have a strong tendency to grow obese after the first few months, and the obesity is accompanied by increased intake of water and production of urine, which reacts positively in glucose tests.

(vii) Fidget (fi). This recessive gene, first reported by Grüneberg (1943), affects the eyes and the feet, in addition to the inner ear. Fidget mice can hear, but their behaviour resembles that of other shaker-waltzer type mutants, except that the shaking movements of the head occur in the horizontal plane. The pathology has 


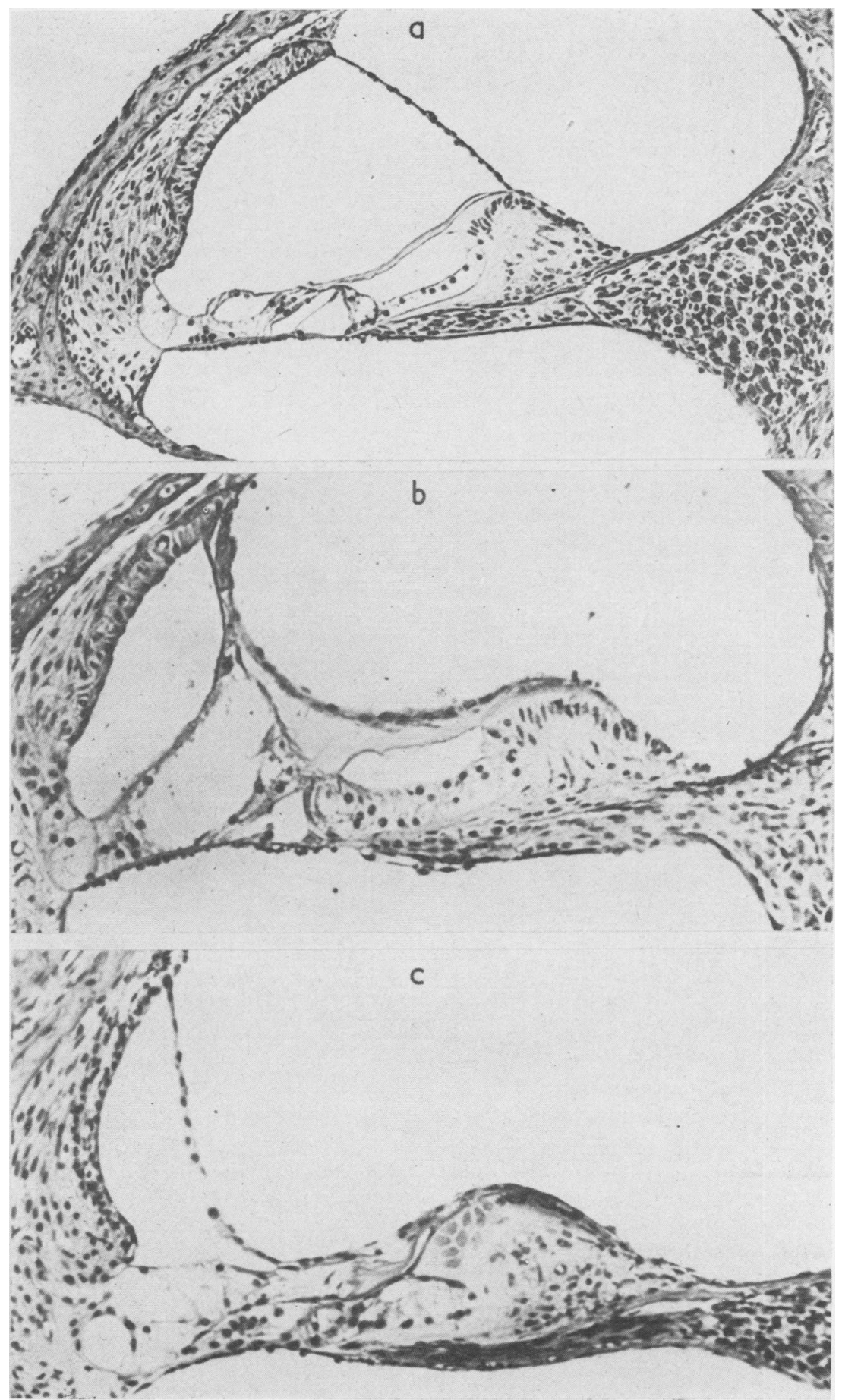

Fig. 1. Scheibe type abnormalities in the cochlea of the mouse. (a) Normal, 21 days old; (b) piebald-lethal, 21 days old; (c) shakerwith-syndactylism, 21 days old. 


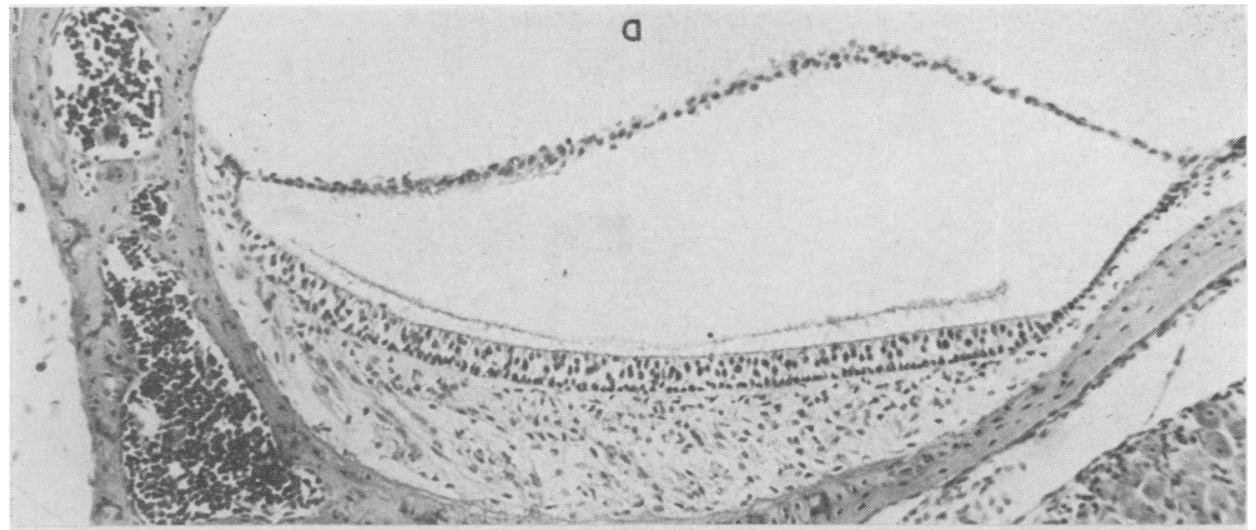

FIg. 2. Scheibe type abnormalities in the saccule of the mouse. with-syndactylism, 21 days old.

(a) Normal, 21 days old; (b) piebald-lethal, 21 days old; (c) shaker-

been studied in detail by Truslove (1956). The cochlea is normal and so are the saccule and utricle, apart from a slight change in shape. The semicircular canals are invariably abnormal. The horizontal canal is usually missing altogether, and the other two, when present, are grossly malformed. The crista of the horizontal canal is never present. The otic capsule lacks a subarcuate fossa, and consequently the floccular and parafloccular lobes of the cerebellum are displaced. The eyes, in particular the lens, are considerably reduced. The feet are frequently polydactylous.

Developmentally, the abnormalities of the eyes appear first (Truslove, 1956). The lens vesicle is reduced in size in 10-day embryos, which is soon after it has been budded off. The abnormalities of the inner ear appear about two days later, when the semicircular canals normally begin to take shape, which does not happen in this case.

(vii) Waltzer-type (Wt). This semi-dominant gene was described by Stein and Huber (1960), who also investigated its morphological effects. Its penetrance appears to be complete as far as the malformations of the inner ear are concerned, but not with regard to behaviour. 
The hearing ability is unaffected. The behaviour is of the shaker-waltzer type, but highly variable. The abnormalities are confined to the semicircular canals, or more precisely to the lateral and posterior canals, the superior one being always normal. The affected canals may be reduced, otherwise distorted, or even missing in part. The cristae appear to be normal. The development of the mutant has not been studied.

(ix) Zigzag. No symbol has been given for this mutant because there is considerable doubt whether a single gene is involved or more. Lyon (1960), who described it, thinks it may well be a polygenic condition. The affected animals have a slight tendency to run in circles, and to move their heads from side to side. The hearing is normal. The abnormalities of the inner ear, which are often asymmetrical, are confined to the lateral semicircular canals which may be malformed, incomplete, or absent. The ampulla is always normal.

(x) Pallid (pa). First described as a recessive gene causing dilution of the coat colour, pallid has been found to affect the inner ear as well (Lyon, 1951, 1953). The homozygotes can hear normally, but their postural reflexes and responses to change in position and linear acceleration are abnormal. Frequently they hold their heads tilted to one side when young, but this trait disappears later on. The penetrance of the gene with regard to its effects on the inner ear varies from stock to stock. The affected animals lack the otoliths in one or both maculae in one or both ears. The maculae appear to be normal in other respects; Lyon (1951) has shown that the correlation between tilting of the head and unilateral absence of otoliths can best be explained on the assumption that the saccule has an equilibratory function in mammals. The absence of the otoliths can be detected as early as the 16th day of embryonic life (Lyon, 1955b).

In their work on nutritional deficiencies, Hurley and collaborators (Hurley, Everson, and Geiger, 1958; Hurley et al., 1960) had found that offspring of female rats fed on a manganese-deficient diet had abnormal behaviour. Since this behaviour resembled that of pallid mice, they (Erway, Hurley, and Fraser, 1966) tried feeding pallid females during pregnancy on a diet with high manganese content, and it was discovered that the abnormality of behaviour and the otoliths disappeared in the offspring, though the pigmentary defect remained unchanged.

(xi) Piebald-lethal (s1). This mutation at the piebald locus affecting pigmentation was first described by Lane (1966). The homozygotes are almost entirely white, and suffer from megacolon accompanied by a reduction of the myenteric ganglion. Deafness is common but the behaviour appears to be normal. The cochlea and the saccule are always affected (Deol, 1967). The gross morphogenesis seems to be normal, but there are severe abnormalities of fine differentiation. The tectorial membrane is distorted, and the stria vascularis is either too thin or too thick and otherwise malformed.
The neural epithelium in the organ of Corti is poorly formed, with a large number of cells missing or misshapen. The macula of the saccule has similar abnormalities of the sensory cells, accompanied by striking irregularities of the otolith layer. In many animals the Reissner's membrane in the cochlea is attached to the tectorial membrane, the organ of Corti, and even the stria vascularis (Fig. 1), and the free wall in the saccule is attached to the macula (Fig. 2), both in much the same manner as in the mutant shaker-with-syndactylism.

(xii) White (Miwh). A semi-dominant gene causing widespread spotting, it was first described by Grobman and Charles (1947). The behaviour of the heterozygotes and homozygotes appears to be normal. The effects of this gene have not been systematically investigated but in Kocher's (1960a) study of surdescens (see II.2 below) a number of white heterozygotes were included. Two types of abnormalities of the inner ear were found and both were attributed to the surdescens gene. As one type of abnormality (Type 2) closely resembled the effects of the gene piebald-lethal described above, a further analysis of his data was carried out by Deol (1967). It was found that this type of abnormality was confined to animals carrying the gene white.

Several other genes, such as extra-toes (Johnson, 1967), splotch, and loop-tail (Deol, 1966a), also produce malformations in the inner ear in the homozygous condition, but as these genotypes do not survive birth for more than a few hours at the most, they have not been included.

\section{II.2: Genes with Degenerative Effects}

In this group of mutants the morphogenesis of the inner ear takes place along normal lines. The fine differentiation also appears to be normal, at least until the final stages. Then degeneration of various structures, mostly neural elements, sets in. The time of onset varies in different parts of the inner ear, the cochlea being the first part to be affected. The speed of degeneration also varies in the same way. Although there are important differences between the mutants, the general pattern of degeneration is so similar in all of them that the most economical way of dealing with them would be to give an account of the degenerative processes in all structures and then to point out how far it is applicable to any particular mutant.

Cochlea. The first clear signs of degeneration appear in the cochlea at about the age of 13 days. The hair cells begin to grow smaller and their nuclei start moving towards the top of the organ of Corti. At the same time the various types of supporting cells begin to lose their identity. Within a few weeks the hair cells disappear altogether and the supporting cells form a dedifferentiated mass. In later stages the dedifferentiated mass frequently 


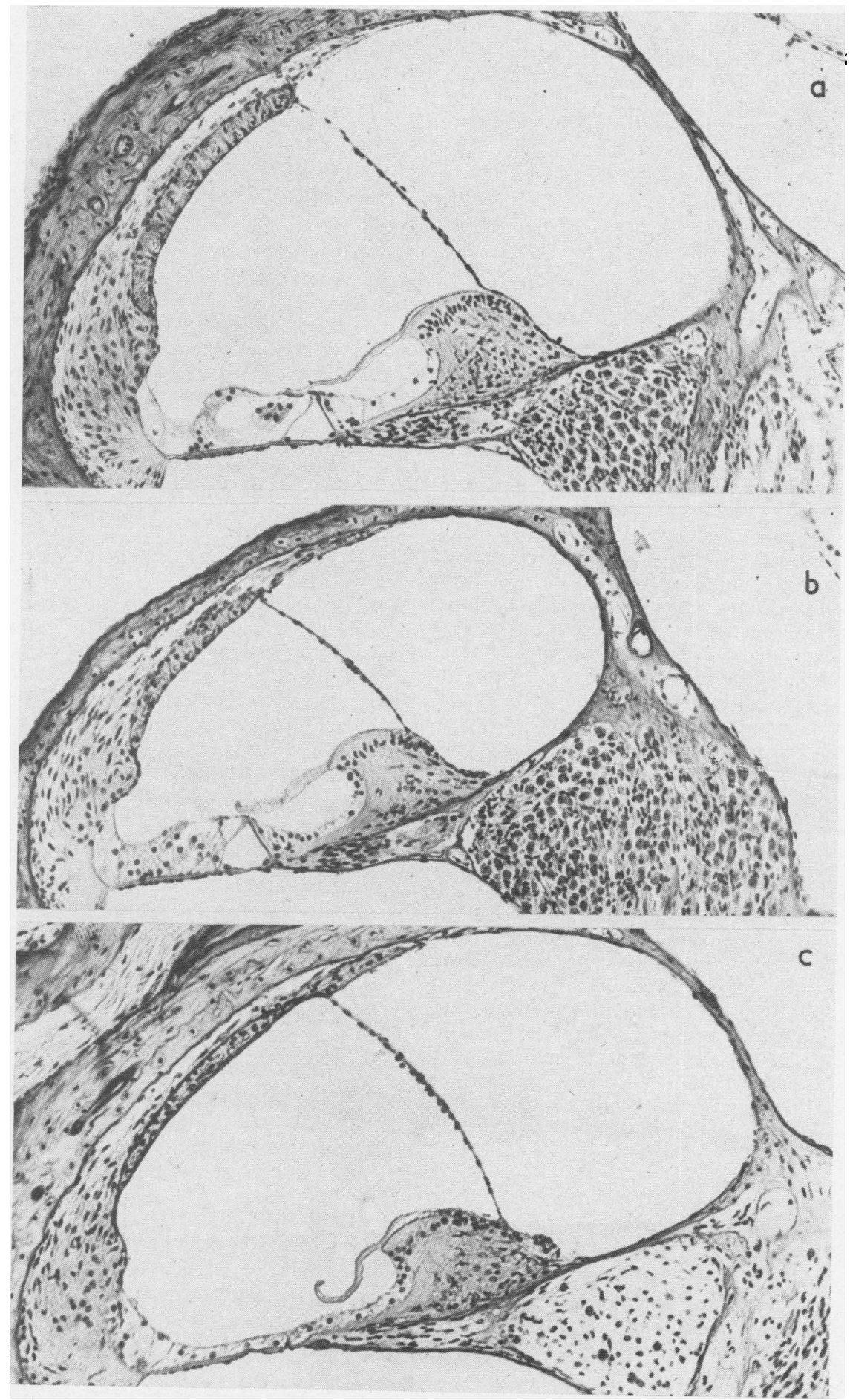
Fig. 3. Degenerative abnormalities in the cochlea of the mouse. (a) Normal, 59 days old; (b) shaker-2, 100 days old, moderate de-
generation; (c) shaker-1, 268 days old, advanced degeneration. 
invades the tunnel of Corti. In some cases even the rods disintegrate and no trace of the tunnel is left in parts of the scala media. Meanwhile the tectorial membrane has lost touch with the organ of Corti and become distorted. The degeneration of the stria vascularis takes place in parallel with that of the organ of Corti. The stria grows thinner or becomes vacuolated; some of its blood vessels are lost, while others dilate abnormally. The degeneration of the spiral ganglion becomes evident a little later; its cells gradually shrink and then often disappear altogether. In the early stages it appears to be somewhat loosely packed, whereas in older animals the spiral canal is virtually empty (Fig. 3 ).

Saccule. The degeneration of the saccular macula takes place considerably later than that of the cochlear structures. Some of the epithelial cells disintegrate, and the others lose their columnar appearance and grow large and rounded, with clear cytoplasm surrounding a central nucleus. The hairs are lost or withdrawn in the process. Eventually these cells also disintegrate, and the otoliths come to rest on the layer of supporting cells. In old animals even the supporting cells tend to lose their orderly arrangement and the otolith layer may be broken up and scattered (Fig. 4).

Utricle and Semicircular Canals. The degeneration of the utricular macula is very similar to that of the saccular macula, except that it usually stops short of the final stages. Some hair cells, however abnormal in appearance, always remain. The onset is later than in the saccule, and the speed slower. Allowing for the differences in structure, the degeneration of the cristae closely resembles that of the utricle. The remnants of the hair cells never completely disappear (Fig. 5). There is no obvious difference between the cristae of various canals in this respect.

Vestibular Ganglion. This ganglion is only slightly affected when compared with the spiral ganglion, and even this happens rather late. Most of the ganglion cells shrink to some extent, but there does not appear to be any appreciable cell loss.

The only gene that is known to cause all the changes described above is snell's waltzer ( $s v$; Deol and Green, 1966). The semi-dominant gene varitint-waddler ( $\mathrm{Va}$; Cloudman and Bunker, 1945) affects all the structures with the exception of the utricular macula, the homozygotes being more severely affected than the heterozygotes (Deol, 1954). In the mutant jerker ( $j e$; Grüneberg, Burnett, and Snell, 1941), on the other hand, the
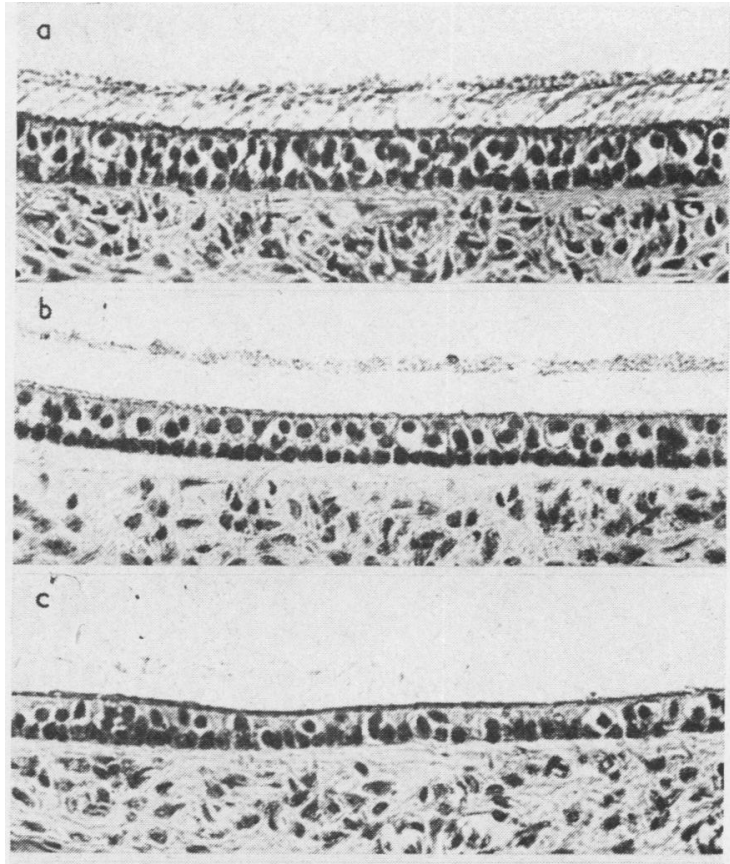

"d

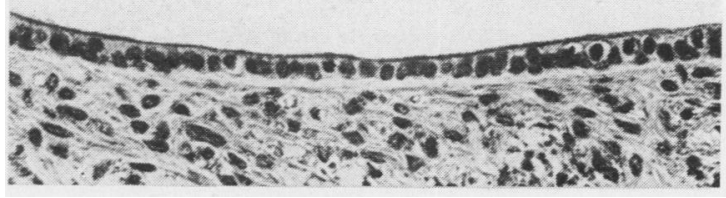

FIG. 4. Degenerative abnormalities in the saccular macula of the mouse. (a) Normal, 240 days; (b) shaker-1, 67 days old, slight degeneration; (c) shaker-1, 367 days old, moderate degeneration; (d) shaker-1, 367 days old, advanced degeneration.

utricular macula is involved, but the cristae and the vestibular ganglion are not (Deol, 1954). The mutants waltzer ( $v$; Grüneberg, 1952), shaker-2 (sh-2; Dobrovolskaia-Zavadskaia, 1928), pirouette ( $p i$; Woolley and Dickie, 1945), and spinner (sr; Deol and Robins, 1962) all have normal cristae and utricular maculae, the remaining structures being affected (Deol, 1954, 1956a). There are minor differences such as the persistence of some hair cells in the organ of Corti in old pirouette mice (Deol, 1956a; Sidman et al., 1966) and the fairly normal appearance of the vestibular ganglion in most waltzer mice. The mutant shaker-1 (sh-1; Lord and Gates, 1929) resembles the waltzer-spinner group, except that the degeneration of the organ of Corti is delayed by 3 or 4 weeks during which period the animals can hear (Grüneberg, Hallpike, and Ledoux, 1940; Deol, 1956a). The behaviour of all these mutants is of the shaker-waltzer type. 


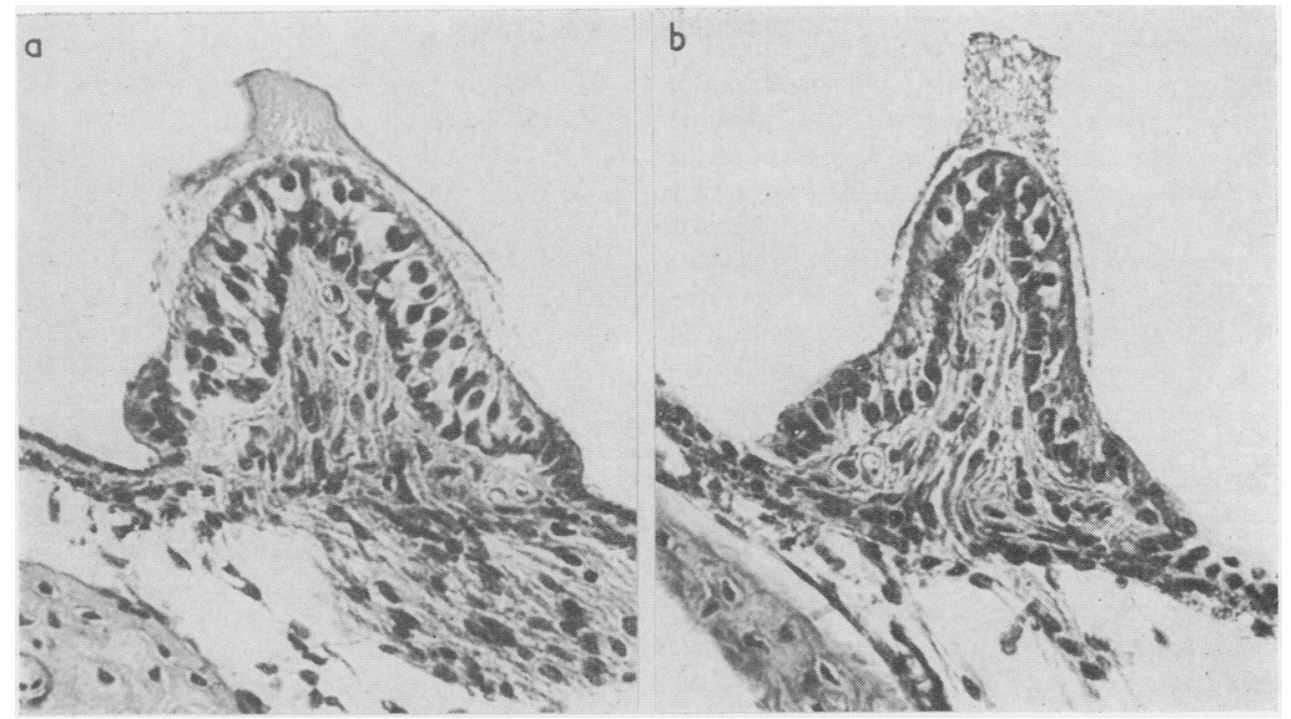

Fig. 5. Degenerative abnormalities in the lateral crista of the mouse. (a) Normal, 240 days old; (b) varitint-waddler, 240 days old, advanced degeneration.

The gene deafness ( $d n$; Deol and Kocher, 1958) invariably affects the cochlea, but not the saccular macula, which is often normal. The effects of the gene deaf, an allele of waltzer $\left(V^{d f}\right.$; Deol, 1956b; Kocher, 1960b), are restricted to the cochlea. Both these mutants are deaf, but their behaviour is otherwise fairly normal. Another mutant, surdescens (su; Kocher, 1960a), resembles deafness in pathology, but differs in that the loss of hearing does not take place until the animals are some months old.

In this group of mutants shaker-1 occupies a special place in that it is the only one that has been the subject of diverse types of studies. Grüneberg et al. (1940) measured the electrical responses of the cochlea, and these measurements have recently been extended to the whole of the VIII nerve by Mikaelian and Ruben (1964) and Mikaelian, Alford, and Ruben (1965). The action potentials of the VIII nerve are present in a weak form until the age of 22 days when they disappear. Zimmermann (1935) reported some atrophy of the corpus striatum and a slight internal hydrocephalus in shaker-1 mice. More recently, Kikuchi and Hilding (1965) who have carried out an extremely interesting electronmicroscopical study of the mutant, found that efferent nerve fibres in the cochlea are largely absent, and that the few fibres that are present arrive later than normal. The first signs of degeneration of the hair cells in the organ of Corti coincide with the nonarrival of these fibres.

\section{II.3: Genes with both Morphogenetic and Degenerative Effects}

Only one gene has been discovered so far that falls into this category: it is rotating $(\mathrm{rg}$; Deol and Dickie, 1967). The homozygotes have shaker-waltzer type behaviour of variable intensity. The hearing ability is normal, and the degenerative effects are confined to the saccular macula, which is affected in exactly the same way as in ordinary degenerative type mutants. But, in addition, morphogenetic defects in the semicircular canals also occur. The canals have a constriction of variable severity, resulting in complete elimination of the lumen in some cases, somewhere near the middle. The lateral canal is always affected, while the other two or one of them may be normal. The abnormalities of the canals are frequently asymmetrical, whereas the degeneration of the saccular macula is bilateral.

\section{III: MECHANISM OF GENE ACTION}

The disorders of the inner ear in man and the mouse described above cover such a wide range in their pathological and physiological aspects that they must have diverse causes. Some of the diseases may well be due to disturbances of enzymatic balance occurring rather late in life, which may affect the inner ear either by themselves or in conjunction with effects on other organs. Others may be caused by toxic damage resulting from some genetically determined pathological process localized elsewhere in the body. But a large number of the 
disorders are obviously developmental in origin and form a single category. In view of the good understanding of the development of the inner ear in vertebrates, it is possible to elucidate to a certain extent the mechanism of gene action in this category. The original product of gene action must of course be chemical in nature here as elsewhere, but some of the steps and pathways through which it leads to an interference with the development of this organ can be determined. For this purpose a brief account of the factors affecting the morphogenesis of the inner ear is desirable.

\section{III.1: Factors Affecting Morphogenesis}

The inner ear arises as an epidermal thickening, the otic placode, in the region of the hind brain, before the neural folds close dorsally. The placode invaginates, and is constricted off to form a closed cavity, the otic vesicle. The vesicle goes through a lengthy process of localized expansion accompanied by divisions and subdivisions to form a complex series of interconnected chambers of various shapes and sizes. During this process it acquires connexions with different branches of the eighth nerve, and develops sensory epithelium in the region of these connexions. In the last stage of the process mesenchymal cells form a dense envelope round it, which eventually chondrifies and ossifies to form the otic capsule. Innumerable experiments have been performed on amphibian and avian embryos-used, on account of their accessibility-to find out what controls various steps in this process and how. Although considerable success has been achieved, the resulting knowledge is far from complete; a process of such complexity must have a number of factors playing a part in it, hardly any of which could be independent.

The results of these experiments may be summarized as follows. The ectoderm in the region of the future otic placode acquires its ear-forming capacity in very early stages, probably as a result of the inductive influence of the underlying mesoderm (Zwilling, 1941; Hörstadius, 1950). Once this capacity has been acquired it will continue to develop in the normal direction for a limited time even when transplanted to some other part of the embryo. When the ear vesicle stage is reached the hind brain comes in as the dominant inductive influence (Waddington, 1937; Harrison, 1945; Yntema, 1950; Detwiler and van Dyke, 1950). The vesicle will not grow normally unless it is in contact with a certain region of the medulla. If the medulla is replaced with some other part of the neural tube the development of the ear goes astray and soon comes to an end, and if the medulla is grafted under the ectoderm in some other part of the head an ear vesicle is induced, but it is not normal. What is essential is a combination of the presumptive ear ectoderm and the medulla. Some other factors are also suspected of playing considerable roles at this stage, the most important of them being the acoustic ganglion. But again the important point is that none of them acts independently of the others.

When all progresses normally and the gross morphogenesis reaches its final stage the labyrinth becomes surrounded by a capsule of mesenchymal cells. There is a good deal of evidence that the mesenchymal cells aggregate under the inductive influence of the wall of the labyrinth (Lewis, 1907; Kaan, 1930, 1938). If the labyrinth is removed no condensation of mesenchyme takes place, and a capsule is not formed. If the labyrinth is transplanted to another part of the body where mesenchymal cells of mesodermal origin are available it will form a capsule. Kaan (1938) believed that after its formation the capsule exerted reciprocal inductive influence on further differentiation of the ear, for when the capsule is not present the ear does not differentiate normally; but this view is not tenable, because the fact that a labyrinth did not form a capsule is a sign that it is abnormal in some way and hence cannot be expected to differentiate normally. Moreover, Detwiler and van Dyke (1950) have shown that, when the relevant part of the medulla is removed and the placode allowed to form an abnormal labyrinth, it forms a capsule, but its further differentiation is abnormal just the same.

\section{III.2: Interpretation of Disorders in the Mouse}

The abnormalities of some of the mouse mutants can be interpreted in the light of the transplantation experiments described above. In the mutant kreisler the neural tube in the region of the inner ear is abnormal from the beginning, as shown by its failure to form normal neuromeres and by the degeneration of some of its cells. This is accompanied by the failure of the cells of the facialacoustic ganglionic complex to form an orderly mass, which is probably a consequence of the abnormality of the neuromeres. The ganglionic cells separate the otic vesicle from the neural tube, thus making it comparable to vesicles transplanted to heterotopic positions in the experiments mentioned above. The subsequent development of the vesicle and the range of its abnormalities is much the same in kreisler embryos as in the experimentally treated ones. This leaves little doubt that the primary effect of the kreisler gene is on the neural tube and 
the ganglia in the region of the medulla, and that the abnormalities of the inner ear are the secondary consequences of this effect.

Another mutant in which the neural tube is strongly implicated as the primary site of gene action is dreher. In fact the abnormalities of the neural tube in dreher embryos were discovered only because they were looked for. The defects of the inner ear had suggested that the morphogenesis might have gone wrong in consequence of an interference with the inductive function of the neural tube, and it was found that the neural tube was indeed clearly abnormal in the ear region long before any signs of faulty morphogenesis appeared in the otic vesicle. The main difference from the kreisler mutant is that in dreher, though the neural tube is morphologically abnormal, its spatial relationship with the vesicle is normal, whereas in kreisler the spatial relationship is also affected. This may account for the lesser severity of the malformations in dreher mice.

The discovery of the abnormalities of the neural tube in dreher mice may be taken as evidence that the application of the principles of experimental embryology to mammals is not without foundation. It is further supported by studies on the mutants splotch (Auerbach, 1954) and loop-tail (Stein and Rudin, 1953). The neural tube in these mutants was known to be abnormal from the earliest stages, but nothing was known about the morphogenesis of the inner ear. On investigation, such abnormalities were discovered in both mutants (Deol, 1966a).

In the mutant dancer it was seen that the reduction of the acoustic ganglion and the absence of some of the branches of the eighth nerve could be observed long before any morphogenetic abnormalities appeared in the labyrinth. Moreover, these latter, when they did appear, were restricted to those regions that received their nerve supply from the affected part of the ganglion. This made it highly probable that there was a cause and effect relationship between the two. This mutant also provides strong evidence that the morphogenesis of the proximal end of the semicircular canals is partly governed by their nerves, and this evidence can be used in the interpretation of other mutants.

The abnormalities of piebald-lethal mice can also be traced back to the acoustic ganglion. For this purpose it must be borne in mind that the whiteness of a white spot is fundamentally different from the whiteness of an albino animal. Whereas no melanocytes can be identified in the white regions of a spotted animal, albino skin has clear melanocytes which cannot form pigment on account of a biochemical block (Billingham and Silvers, 1960).
Piebald-lethal homozygotes, which are often entirely white, are to be regarded as one large spot in this respect (the same applies to several all-white phenotypes in a number of other species as well). The piebald locus is known to affect pigmentation primarily because of its action on the neural crest (Mayer, 1965), the source of melanocytes as well as ganglion cells. The involvement of the myenteric ganglion in piebald and piebald-lethal mice (Beilschowsky and Schofield, 1962; Lane, 1966) strongly suggests that the gene action on the neural crest takes place before its differentiation into melanoblasts and ganglionic primordia. From the phenotype of piebald-lethal mice it appears that almost the whole of the neural crest is affected. From these considerations it may reasonably be concluded that the primary neural crest abnormality is reflected in the differentiation of the inner ear through the agency of the acoustic ganglion. The alternative hypothesis would be that the melanocytes themselves in some way affect the inner ear, but no evidence can be found in its support. The presence of some normal neural epithelium in the cochlea with the resulting lack of total deafness in piebaldlethal mice, and the non-involvement of the vestibular part, may be ascribed to the dual origin of the acoustic ganglion, for there is much evidence that it originates in the otic placode (Campenhout, 1935; Yntema, 1937; Halley, 1955; Batten, 1958) as well as in the neural crest (Bartelmez, 1923; Adelmann, 1925). Other possible explanations of the same phenomenon have been given elsewhere (Deol, 1967).

The abnormalities of the mutant white closely resemble those of piebald-lethal, and since white is also a spotting gene the same interpretation may be applied to it. The absence of otoliths in pallid mice, which also have pigmentary anomalies, may have a similar basis. The otoliths are in all probability secreted by the macula (Lyon, 1955a; Deol and Lane, 1966). As the macula arises as a result of interaction between the otic epithelium and the ganglion cells or their external processes, any abnormality of the neural crest may well be transmitted to the macula through the ganglion (for further discussion see Deol, 1967).

The neural tube and the acoustic ganglion have not been examined in other mutants, but they may well be involved in some of them. In the mutant shaker-with-syndactylism there is even some direct evidence that the cerebellum is abnormal. In fidget mice anomalous morphogenesis of the vestibular region of the labyrinth is accompanied by abnormal development of the eyes. This may reflect a fault in the neural tube extending to the prosen- 
cephalon in front, for the primary optic vesicles, which form the main body of the eye and induce the lens (Balinsky, 1960), are merely evaginations of the neural tube. The assumption that the abnormalities of the eyes and the ears in fidget mice are secondary to a primary fault in the neural tube, is supported by the frequent appearance of shakerwaltzer type behaviour in the mutant ocular retardation (Truslove, 1962), which has severe morphogenetic abnormalities of the eyes. Possible explanations of the pleiotropic effects of other genes, such as kinky, have been given by Deol (1966b). A point that often proves useful in the interpretation of pleiotropic mutants is that the primary effects of a gene are more likely to be constant and bilateral than the secondary ones.

It has been argued by Deol (1966b), mainly on the basis of great phenotypical resemblance between the degenerative and morphogenetic mutants, that in degenerative mutants also the basic abnormality may be in the neural tube and the acoustic ganglion, but with the difference that only the life-span or the period of active function of the neural elements and their dependent structures is affected. This view receives support from the findings of Kikuchi and Hilding (1965) that in shaker-1 animals the efferent cochlear fibres are lacking. Since the neurons of these fibres are in the brain, an abnormality of the neural tube is implied. The involvement of the acoustic ganglion is suggested by the abnormality of the stria vascularis, which is not easy to account for by the absence of efferent fibres alone. The pathology of piebald-lethal mice (Deol, 1967) indicates that the acoustic ganglion is an important factor in the development of the stria vascularis. Explanations based on deficiencies of the endolymph put forward in some of the earlier studies fail to meet even the basic requirements of this exceedingly complex problem. The view that there is no sharp division between the morphogenetic and degenerative mutants has been strengthened by the discovery of the gene rotating, which has both types of effects in the same ear.

\section{III.3: Interpretation of Disorders in Man}

In the absence of developmental studies of inherited diseases of the inner ear in man, morphological similarities with mouse mutants form the best basis for interpretations. But whereas in the mouse it is easy to relate certain abnormalities to particular genes, it is rarely possible to do so in man. In most cases it is far from certain whether the same gene is operating in apparently similar families or different genes. Moreover, the number of cases with known pathology from any one family is of necessity very small, and when families differ in some striking respect the natural tendency is to put them into separate pathological categories. But studies on the mouse have shown that the same gene can produce a wide variety of abnormalities even in inbred stocks, and when the effects of the genetic background on the expression of a gene are taken into consideration it is easy to see how fruitless it is to try to relate abnormalities to genes in man when the evidence is slender. In view of this, the abnormalities are probably best treated without reference to genes.

Following Ormerod's (1960) classification of pathological conditions, the Michel type abnormalities have only rarely been observed in inherited disorders in man. No mutant gene is known in the mouse that causes a total absence of the inner ear, but the formless cavities in the petrous bone, which also fall into this class, are often seen in kreisler mice. This strongly suggests that the primary cause of Michel type abnormalities lies in the neural tube. The fact that they are usually associated with severe mental defect supports this view.

Of the next two classes, the Mondini-Alexander type and the Bing-Siebenmann type, the former is commoner in inherited diseases, though on the evidence of mutant mice the grounds for regarding them as two separate entities are not very strong. The abnormalities of many kreisler mice are of these types, but comparison with the mutant dreher is more appropriate, for dreher mice seldom fall out of these classes. In either case an involvement of the neural tube in the early stages of development is implied. Frequent association of defects of the eyes and the central nervous system and mental retardation with abnormalities of these two types strengthens this conclusion.

Most of the inherited disorders in man fall into the fourth class, the Scheibe type. This is particularly true of syndromes including abnormalities of pigmentation: in many reports there are references to a lack of pigment in various organs. The pathology of one case of Waardenburg's syndrome studied by Fisch (1959) is clearly of this type. Almost identical abnormalities occur in association with pigmentary anomalies in animals of many different species. The absence of pigment is not always total, which is a strong indication that these are instances of hypopigmentation and not albinism. There can be little doubt that the abnormality of the inner ear in the mutant piebald-lethal is the same entity as this; the resemblance extends to even details of pathology and phenotype. As discussed earlier, in this mutant all the signs point to a basic defect of the neural crest. It is reasonable to assume that the 
same applies to human disorders. The absence of mental defect in these disorders favours this view. The possibility of the neural crest involvement in man has been mentioned before by Fisch (1959) and Margolis (1962), but without any supporting evidence of the kind given for the piebald-lethal mutant, and without any reference to the distinction between hypopigmentation and albinism.

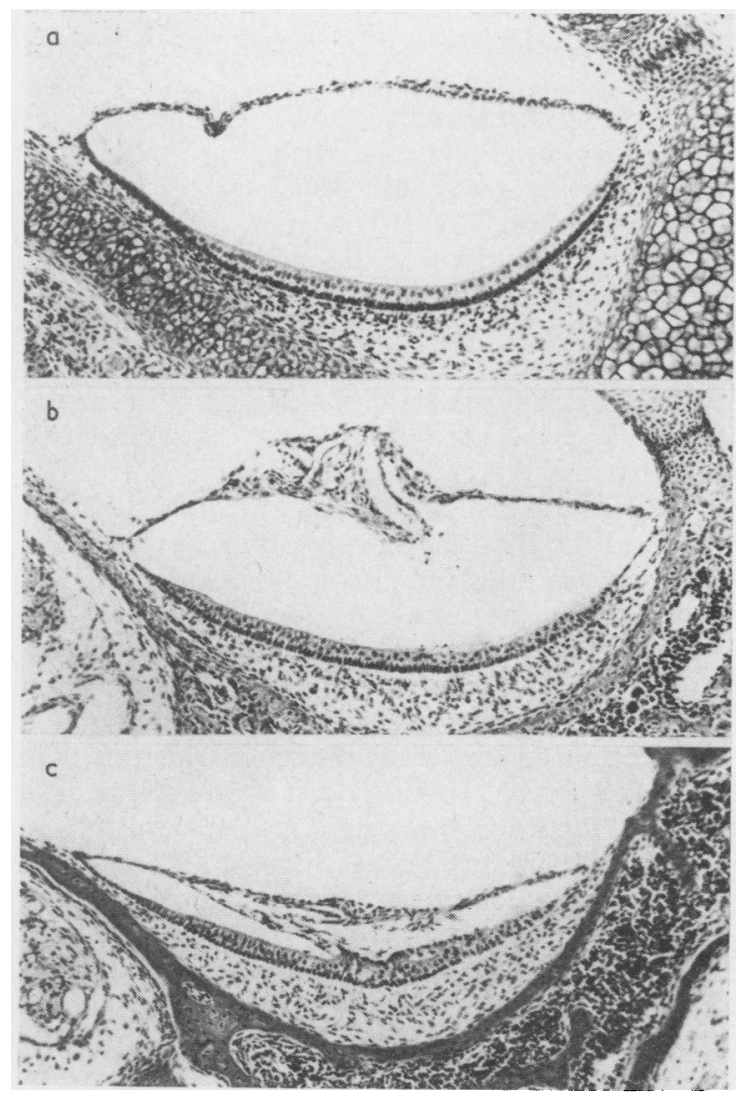

FIG. 6. Development of the Scheibe type abnormality in the saccule in the mutant shaker-with-syndactylism. (a) Newborn; (b) 7 days old; (c) 13 days old.

Ormerod (1960) considers the possibility that the Scheibe type abnormality may be degenerative rather than morphogenetic. The evidence from the mutant shaker-with-syndactylism is against this. The pathology of the cochlea and the saccule in this mutant is almost identical with that in the piebald-lethal (Fig. 1 and 2), but with the advantage that its development has been studied in detail (Deol, 1963). The fine differentiation of the cochlea and saccule is clearly faulty in its final stages. The cavities close as a result of dedifferentiation, and cellular proliferation and migration (Fig. 6). The term 'collapse' as applied to the blockage of spaces in the scala media and the saccule is not justified, particularly when it is explained in terms of a deficiency of the endolymph (Hertwig, 1951). This is also clear from Bosher and Hallpike's (1965) study of white cats: in their illustrations the scala media is closed in some parts and much dilated in others in the same ear, a situation not easily explainable as collapse resulting from reduced pressure of endolymph.

The unilateral abnormalities described by Ever- $\vec{O}$ berg, involving the whole ear or only the cochlea or the vestibule, form an interesting group. As o pointed out by Everberg himself, they are obviously morphogenetic in origin. One may regard unilateral abnormalities, not entirely without reason, as essentially similar in nature to asymmetrical abnormalities. Moreover, it is possible that the apparently normal side may have some slight defect which is not detectable by means of audiometric tests and $x$-ray films. It has been seen that the anomalies of kreisler and dreher mice are often strikingly asymmetrical, and that they can be ascribed to an interference with the inductive function of the neural tube and probably also the acoustic ganglion. The possibility of a similar basis for the unilateral abnormalities in man cannot be ignored. The development of the ear is governed by a large number of interacting factors in a state of balance. It is conceivable that when one of them is altered the balance is disturbed and a thresholdtype situation results, the other factors sometimes succeeding in keeping the development proceeding along normal pathways and sometimes not. The mutant kinky is even more relevant to this problem, but its development has not been studied.

Explanations of this kind have a good chance of being correct when malformations of the labyrinth are associated with other neurological disorders, such as abnormalities of the eyes. But when deafness forms a part of a syndrome the other features of which have no known developmental relationship with the nervous system, such explanations cannot be justified. Moreover, supporting evidence of some kind is always essential. It may, of course, be argued that when deafness occurs with defects of ectodermal structures, the primary abnormality of the ear may have arisen in the otic placode. But in the absence of any supporting evidence the suggestion has little value. There are a number of mutants with gross ectodermal malformations, but the inner ear has not been examined in them so far.

It may be mentioned here that Slatis' (1958) suggestion that sometimes deafness may be caused by double or multiple heterozygosity is supported 
by studies on the mouse. Both waltzer and shaker-1 genes are fully recessive, but the double heterozygotes grow deaf in middle life (Lord and Gates, 1929; Deol, 1956a; Kocher, 1960b).

\section{IV: WIDER CONSIDERATIONS}

Abnormalities of the inner ear of a non-hereditary nature cover as wide a range as those with a genetic origin, and the literature has been reviewed by Altmann (1953) and by Ormerod (1960). Some of them evidently arise from haemorrhage into the labyrinth as a result of some disease or injury. But many bear a close resemblance to the inherited abnormalities discussed above, and it is possible that the causal mechanisms are also similar, though without any hereditary basis. This may be true of congenital malformations in particular, whether sporadic or resulting from some maternal disease or the use of drugs by the mother during pregnancy. Everberg (1960a, b, c) found that there was no clear pathological distinction between the inherited and non-inherited types of unilateral defects of the ear that he studied.

Lindsay et al. (1953) have described the pathoiogy of a child exposed to maternal rubella during development, with total deafness on one side and some residual hearing on the other. The abnormalities were in all respects of the Scheibe type, and could easily have arisen if the disease had primarily affected the acoustic ganglion. Another case, with measles instead of rubella, has been reported by Lindsay and Hemenway (1954), the pathology being of the degenerative type.

This method of analysing the abnormalities for determining the time, site, and manner of gene action may also be applied to inherited diseases of other organs, if something is known about the factors participating in the development of the organ concerned and suitable mutants are available. Inherited disorders of the eyes appear to be especially ripe for this approach, for innumerable experiments on amphibian and bird embryos have illuminated many aspects of the development of the eye. In addition, a number of promising mutants are available (Sidman et al., 1965). To a lesser extent the same may be said of some other structures such as the limbs and the kidneys. A great advantage of this type of approach is that when the abnormality under scrutiny occurs as a part of a syndrome, the other features of the syndrome act as potential clues instead of serving to confuse the picture.

The association of defects of pigmentation with abnormalities of the inner ear raises a question that is worth investigating. As mentioned earlier, in defects of the spotting type the melanocytes are be- lieved to be lacking. But not all pigmentary defects are so severe. In many cases the pigment is formed, but it is not typical of the organism. It is possible that in such cases, too, the acoustic ganglion is involved and in consequence the function of the inner ear disturbed. The mutant pallid may be taken as an example of this. The pigment is formed but it is quantitatively or qualitatively abnormal, and the utricle and the saccule are affected. In another similar mutant, not yet described, there is even some evidence of the involvement of the cochlea (M. S. Deol and P. W. Lane, unpublished). In view of this, the possibility cannot be disregarded that there might be some subtle deficiency of hearing in persons with low grade pigmentation of the skin, hair, and eyes, or with some unusual type of complexion, which sometimes may be detectable by means of audiometric tests.

Finally, it should be mentioned that the mouse mutants discussed in this review by no means exhaust the subject. Many have been found but not yet described, and every year sees the discovery of several new ones.

\section{REFERENCES}

Adelmann, H. B. (1925). The development of the neural folds and cranial ganglia of the rat. f. comp. Neurol., 39, 19.

Altmann, F. (1953). Malformations, anomalies and vestigial structures of the inner ear. Arch. Otolaryng., 57, 591.

Arnvig, J. (1955). Vestibular function in deafness and severe hardness of hearing. Acta oto-laryng. (Stockh.), 45, 283.

- (1959). The syndrome of Waardenburg. Acta genet. (Basel), $9,41$.

Auerbach, R. (1954). Analysis of the developmental effects of a lethal mutation in the house mouse. F. exp. Zool., 127, 305.

Balinsky, B. I. (1960). An Introduction to Embryology. W. B. Saunders, Philadelphia.

Bartelmez, G. W. (1923). The subdivisions of the neural folds in man. f. comp. Neurol., 35, 231.

Batsakis, J. G., and Nishiyama, R. H. (1962). Deafness with sporadic goiter (Pendred's syndrome). Arch. Otolaryng., 76, 401.

Batten, E. H. (1958). The origin of the acoustic ganglion in the sheep. F. Embryol. exp. Morph., 6, 597.

Beilschowsky, M., and Schofield, G. C. (1962). Studies of megacolon in piebald mice. Aust. F. exp. Biol. med. Sci., 40, 395.

Billingham, R. E., and Silvers, W. K. (1960). The melanocytes of mammals. Quart. Rev. Biol., 35, 1.

Bonnevie, K. (1936). Abortive differentiation of the ear vesicles following a hereditary brain-anomaly in the 'short-tailed waltzing mice'. Genetica, 18, 105.

Bosher, S. K., and Hallpike, C. S. (1965). Observations on the histological features, development and pathogenesis of the inner ear degeneration of the deaf white cat. Proc. roy. Soc. B, 162, 147.

Brain, W. R. (1927). Heredity in simple goitre. Quart. F. Med., 20, 303.

Campenhout, E. van (1935). Experimental researches on the origin of the acoustic ganglion in amphibian embryos. F. exp. Zool., 72, 175.

Caspari, E., and David, P. R. (1940). The inheritance of a tail abnormality in the house mouse. f. Hered., 52, 241.

Chung, C. S., Robison, O. W., and Morton, N. E. (1959). A note on deaf mutism. Ann. hum. Genet., 23, 357.

Cloudman, A., and Bunker, L. E. (1945). The varitint-waddler mouse. F. Hered., 36, 259. 
Cohen, M. M., Cassady, G., and Hanna, B. L. (1961). A genetic study of hereditary renal dysfunction with associated nerve deafness. Amer. F. hum. Genet., 13, 379.

Denny-Brown, D. (1951). Hereditary sensory radicular neuropathy. F. Neurol. Neurosurg. Psychiat., 14, 237.

Deol, M. S. (1954). The anomalies of the labyrinth of the mutants varitint-waddler, shaker-2 and jerker in the mouse. f. Genet., 52, 562.

- (1956a). The anatomy and development of the mutants pirouette, shaker-1 and waltzer in the mouse. Proc. roy. Soc. B, 145, 206.

(1956b). A gene for uncomplicated deafness in the mouse. f. Embryol. exp. Morph., 4, 190.

(1963). The development of the inner ear in mice homozygous for shaker-with-syndactylism. ibid., 11, 493.

- (1964a). The abnormalities of the inner ear in kreisler mice. ibid., 12, 475.

(1964b). The origin of the abnormalities of the inner ear in dreher mice. ibid., 12, 727.

- (1966a). Influence of the neural tube on the differentiation of the inner ear in the mammalian embryo. Nature (Lond.), 209, 219.

- (1966b). The probable mode of gene action in the circling mutants of the mouse. Genet. Res., 7, 363.

- (1967). The neural crest and the acoustic ganglion. f. Embryol. exp. Morph., 17, 533.

, and Dickie, M. M. (1967). Rotating, a new gene affecting behavior and the inner ear in the mouse. F. Hered., 58, 69 .

-, and Green, M. C. (1966). Snell's waltzer, a new mutation affecting behaviour and the inner ear in the mouse. Genet. Res., Heredity, 12, 463.

, and Lane, P. W. (1966). A new gene affecting the morphogenesis of the vestibular part of the inner ear in the mouse. $\mathcal{f}$. Embryol. exp. Morph., 16, 543.

53, and Robins, M. W. (1962). The spinner mouse. F. Hered., $53,133$.

Deraemaeker, R. (1958). Sex-linked congenital deafness. Acta genet. (Basel), 8, 228.

- (1960). Recessive congenital deafness in a North Belgian province. ibid., 10, 295.

Detwiler, S. R., and van Dyke, R. H. (1950). The role of the medulla in the differentiation of the otic vesicle. F. exp. Zool., 113, 179 .

Dobrovolskaia-Zavadskaia, N. (1928). L' irradiation des testicules et l' hérédite chez la souris. Arch. Biol. (Paris), 38, 457.

Dolowitz, D. A., and Stephens, F. E. (1961). Hereditary nerve deafness. Ann. Otol. (St. Louis), 70, 851.

Dow, G. S., and Poynter, C. I. (1930). The Dar family. Eugen. News, 15, 128.

Dubach, U. C., and Gsell, O. R. (1962). Alport's syndrome. Lancet, $1,159$.

Dunn, L. C. (1934). A new gene affecting behaviour and skeleton in the house mouse. Proc. nat. Acad. Sci. (Wash.), 20, 230.

the and Gluecksohn-Waelsch, S. (1954). A genetical study of the mutation 'fused' in the house mouse, with evidence concerning its allelism with a similar mutation 'kink'. F. Genet., 52, 383.

Erway, L., Hurley, L. S., and Fraser, A. (1966). Neurological defect: manganese in phenocopy and prevention of a genetic abnormality of inner ear. Science, 152, 1766.

Everberg, G. (1955). Labyrinthine disease in identical twins. Acta oto-laryng. (Stockh.), 45, 198.

(1957). Hereditary unilateral deafness. ibid., 47, 303.

(1960a). Unilateral anacusis. Clinical, radiological and genetic investigations. ibid., Suppl., 158, 366 . ibid., 51,615 . Further studies on hereditary unilateral deafness.

(1960c). Investigations into unilateral total deafness and absence of vestibular function with a particular view to the X-ray appearances in the inner ear. ibid., 52, 47 .

Falconer, D. S., and Sierts-Roth, U. (1951). Dreher, ein neues Gen der Tanzmausgruppe bei der Hausmaus. Z. indukt. Abstamm.-u. Vererb.-L., 84, 71.

Feinmesser, M., and Zelig, S. (1961). Congenital deafness associated with onychodystrophy. Arch. Otolaryng., 74, 507.

Fisch, L. (1959). Deafness as part of an hereditary syndrome. $f$.
Laryng., 73, 355.
Fischer, H. (1956). Morphologische und mikroskopisch-anato- ( mische Untersuchungen am Innenohr eines Stammes spontanmutierter Hausmäuse (dreher). Z. mikr.-anat. Forsch., 62, 348.

- (1957). Untersuchungen am Innenohr einer bewegungsgestörten, tauben Hausmausmutante im Vergleich mit der vererbbaren, labyrinthären Hörstörung des Menschen. Arch. Ohr.-, Nas.-, u. Kehlk.-Heilk., 170, 411.

- (1958). Die Embryogenese der Innenohrmissbildungen bei dem spontanmutierten Dreherstamm der Hausmaus. Z. mikr.anat. Forsch., 64, 476.

Flynn, P., and Aird, R. B. (1965). A neuroectodermal syndrome of dominant inheritance. F. neurol. Sci., 2, 161.

Fraser, G. R. (1964a). Profound childhood deafness. F. med. ڤ్ Genet., $1,118$.

- (1964b). A study of causes of deafness in 2,355 children in $\vec{O}$ special schools. In Research in Deafness in Children, p. 10. Ed. by L. Fisch. Blackwell, Oxford.

(1964c). Studies in isolates. F. Génét. hum., 13, 32.

(1965a). Association of congenital deafness with goitre (Pendred's syndrome). A study of 207 families. Ann. hum. Genet., 28, 201

(1965b). Sex-linked recessive congenital deafness and the $v$ excess of males in profound childhood deafness. ibid., 29, 171.

-, Frogatt, P., and James, T. N. (1964a). Congenital deafness $\vec{\omega}$ associated with electrocardiographic abnormalities, fainting attacks and sudden death-a recessive syndrome. Quart. F. Med., 33, 361 .

- - and Murphy, T. (1964b). Genetical aspects of the $\overrightarrow{-}$ cardio-auditory syndrome of Jervell and Lange-Nielsen (con- $\overleftarrow{E}$ genital deafness with electrocardiographic abnormalities). $A n n$. hum. Genet., 28, 133.

$\longrightarrow$, Morgans, M. E., and Trotter, W. R. (1960). The syndrome of $\overrightarrow{0}$ sporadic goitre and congenital deafness. Quart. F. Med., 29, 279.

Grobman, A. B., and Charles, D. R. (1947). Mutant white mice. A $\odot$ new dominant autosomal mutant affecting coat color in Mus musculus. F. Hered., 38, 381.

Groll, A., and Hirschowitz, B. I. (1966). Steatorrhea and familial deafness in two siblings. Clin. Res., 14, 47.

Grüneberg, H. (1943). Two new mutant genes in the house mouse. f. Genet., 45, 22.

(1952). The Genetics of the Mouse, 2nd ed. Martinus Nijhoff, The Hague.

- (1956). Hereditary lesions of the labyrinth in the mouse. Brit. med. Bull., 12, 153.

- (1963). The Pathology of Development. Blackwell Scientific Publications, Oxford.

—, Burnett, J. B., and Snell, G. D. (1941). The origin of jerker, new gene mutation of the mouse, and linkage studies made with it. Proc. nat. Acad. Sci. (Wash.), 27, 562.

- Hallpike, C. S., and Ledoux, A. (1940). Observations on the structure, development and electrical reactions of the internal ear of the shaker-1 mouse. (Mus musculus). Proc. roy. Soc. B, 129, 154.

Halley, G. (1955). The placodal relations of the neural crest in the domestic cat. F. Anat. (Lond.), 89, 133.

Hallgren, B. (1959). Retinitis pigmentosa combined with congenital deafness; with vestibulo-cerebellar ataxia and mental abnormality in a proportion of cases. A clinical and genetico-statistical study Acta psychiat. scand., 34, Suppl., 138.

Hansen, A. C., Ackaouy, G., and Crump, E. P. (1965). Waardenburg's syndrome. Report of a pedigree. $f$. nat. med. Ass. (N.Y.), 57, 8.

Harrison, R. G. (1945). Relations of symmetry in the developing embryo. Trans. Conn. Acad. Arts Sci., 36, 277.

Helweg-Larsen, H. F., and Ludvigsen, K. (1946). Congenital familial anhidrosis and neurolabyrinthitis. Acta derm.-venereol. (Stockh.), 26, 489.

Herrmann, C., Aguilar, M. J., and Sacks, O. W. (1964). Hereditary photomyoclonus associated with diabetes mellitus, deafness, nephropathy and cerebral dysfunction. Neurology (Minneap.), 14, 212.

Hertwig, P. (1942a). Neue Mutationen und Koppelungsgruppen bei der Hausmaus. Z. indukt. Abstamm.-u. Vereb-L., 80, 220.

- (1942b). Sechs neue Mutationen bei der Hausmaus in ihre Bedeutung für allgemeine Vererbungsfragen. $Z$. menschl. Vererb.-u Konst.-Lehre, 26, 1.

- (1944). Die Genese der Hirn- und Gehörorganmissbildungen bei röntgenmutierten Kreisler-Mäusen. ibid., 28, 327. 
- (1951). Entwicklungsgeschichtliche Untersuchungen über Bewegungsstörungen bei Mäusen. Verh. anat. Ges. (fena) (49, Vers. in Heidelberg, 1951), 97.

- (1956). Erbliche Missbildungen des Gehörorgans bei der Maus. ibid. (53, Vers. in Stockholm, 1956), 256.

Hicks, E. P. (1922). Hereditary perforating ulcer of the foot. Lancet, 1, 319.

Hollander, C. S., Prout, T. E., Rienhoff, M., Ruben, R. J., and Asper, S. P. (1964). Congenital deafness and goiter. Studies of a patient with a cochlear defect and inadequate formation of iodothyronines. Amer. F. Med., 37, 630.

Hopkins, L. A., and Guilder, R. P. (1949). Clarke School Studies Concerning the Heredity of Deafness. Monograph No. 1. Pedigree Data 1930-1940. Clarke School for the Deaf, Northampton, Massachusetts.

Hörstadius, S. (1950). The Neural Crest. Oxford University Press, London.

Houghton, N. I. (1964). Waardenburg's syndrome with deafness as the presenting symptom. Report of two cases. N.Z. med. F., $63,83$.

Hurley, L. S., Everson, G. J., and Geiger, J. F. (1958). Manganese deficiency in rats: congenital nature of ataxia. $\mathcal{F}$. Nutr., 66, 309.

-, Wooten, E., Everson, G. J., and Asling, C. W. (1960). Anomalous development of ossification in the inner ear of offspring of manganese-deficient rats. ibid., $\mathbf{7 1}, 15$.

Jervell, A., and Lange-Nielsen, F. (1957). Congenital deaf-mutism, functional heart disease with prolongation of the Q-T interval, and sudden death. Amer. Heart F., 54, 59.

Johnsen, S. (1958). Familial deafness and goitre in persons with a low serum level of protein-bound iodine. Acta oto-laryng. (Stockh.), Suppl., 140, 168.

Johnson, D. R. (1967). Extra-toes: a new mutant gene causing multiple abnormalities in the mouse. f. Embryol. exp. Morph. $17,543$.

Kaan, H. W. (1930). The relation of the developing auditory vesicle to the formation of cartilage capsule in Amblystoma punctatum. F. exp. Zool., 55, 263.

(1938). Further studies on the auditory vesicle and cartilaginous capsule of Amblystoma punctatum. ibid., 78, 159.

Kikuchi, K., and Hilding, D. A. (1965). The defective organ of Corti in shaker-1 mice. Acta oto-laryng. (Stockh.), 60, 287.

Kloepfer, H. W., Laguaite, J. K., and Mclaurin, J. W. (1966). The hereditary syndrome of congenital deafness and retinitis pigmentosa (Usher's syndrome). Laryngoscope (St Louis), 76, 850.

Kocher, W. (1960a). Untersuchungen zur Genetik und Pathologie der Entwicklung spät einsetzender hereditärer Taubheit bei der Maus. (Mus musculus). Arch. Ohr.-, Nas.-, u. Kehlk.-Heilk., $177,108$.

- (1960b). Untersuchungen zur Genetik und Pathologie der Entwicklung von 8 Labyrinthmutanten (deaf-waltzer-shakerMutanten) der Maus (Mus musculus). Z. indukt. Abstamm.-u. Vererb.-L., 91, 114.

Koroxenidis, G. T., Webb, N. C., Moschos, C. B., and Lehan, P. H. (1966). Congenital heart disease, deaf-mutism and associated somatic malformations occurring in several members of one family. Amer. F. Med., 40, 149.

Lane, P. W. (1966). Association of megacolon with two recessive spotting genes in the mouse. F. Hered., 57, 29.

Lang, H. A. (1959). Retinal degeneration and nerve deafness. Brit. med. F., 2, 1096.

Latham, A. D., and Munro, T. A. (1937). Familial myoclonus epilepsy associated with deaf-mutism in a family showing other psychobiological abnormalities. Ann. Eugen. (Lond.), 8, 166.

Lewis, S. M., Sonnenblick, B. P., Gilbert, L., and Biber, D. (1958). Familial pulmonary stenosis and deaf-mutism. Clinical and genetic considerations. Amer. Heart f., 55, 458.

Lewis, W. H. (1907). On the origin and differentiation of the otic vesicle in amphibian embryos. Anat. Rec., 1, 141.

Lindenov, H. (1945). The etiology of deaf-mutism, with special reference to heredity. Op. dom. Biol. hered. hum., Kbh., 8.

Lindsay, J. R., Caruthers, D. G., Hemenway, W. G., and Harrison, S. (1953). Inner ear pathology following maternal rubella. Ann. Otol. (St. Louis), 62, 1201.

, and Hemenway, W. G. (1954). Inner ear pathology due to measles. ibid., 63, 754 .

Lord, E. M., and Gates, W. H. (1929). Shaker, a new mutation in the house mouse. (Mus musculus). Amer. Nat., 63, 435.
Lyon, M. F. (1951). Hereditary absence of otoliths in the house mouse. f. Physiol. (Lond.), 114, 410.

- (1953). Absence of otoliths in the mouse: an effect of the pallid mutant. F. Genet., 51, 638.

- (1955a). The development of the otoliths of the mouse. $f$ Embryol. exp. Morph., 3, 213.

(1955b). The developmental origin of hereditary absence of otoliths in mice. ibid., 3, 230.

- (1958). Twirler: a mutant affecting the inner ear of the house mouse. ibid., 6, 105.

(1960). Zigzag: a genetic defect of the horizontal canals in the mouse. Genet. Res., 1, 189.

McKusick, V. A. (1966). Mendelian Inheritcince in Man. William Heinemann Medical Books, London.

Margolis, E. (1962). A new hereditary syndrome-sex-linked deafmutism associated with total albinism. Acta genet. (Basel), 12, 12.

Marshall, D. (1958). Ectodermal dysplasia. Report of kindred with ocular abnormalities and hearing defect. Amer. F. Ophthal., 45, 143.

Mayer, T. C. (1965). The development of piebald spotting in mice. Develop. Biol., 11, 319.

Mikaelian, D. O., Alford, B. R., and Ruben, R. J. (1965). Cochlear potentials and VIII nerve action potentials in normal and genetically deaf mice. Ann. Otol. (St. Louis), 74, 146.

- , and Ruben, R. J. (1964). Hearing degeneration in shaker-1 mouse. Arch. Otolaryng., 80, 418.

Mitsuda, H., Inoue, S., and Kazama, Y. (1952). Eine Familie mit rezessiv-geschlechtsgebundener Taubstummheit. Fap. F. Genet., 27, 142.

Mohr, J., and Mageröy, K. (1960). Sex-linked deafness of a possibly new type. Acta genet. (Basel), 10, 54.

Muckle, T. J., and Wells, M. (1962). Urticaria, deafness and amyloidosis. A new heredo-familial syndrome. Quart. $\mathcal{7}$. Med., 31, 235.

Mulrow, P. J., Aron, A. M., Gathman, G. E., Yesner, R., and Lubs, H. A. (1963). Hereditary nephritis. Report of a kindred. Amer. F. Med., 35, 737.

Ormerod, F. C. (1960). The pathology of congenital deafness. $\mathcal{F}$. Laryng., 74, 919.

Parker, N. (1958). Congenital deafness due to a sex-linked recessive gene. Amer. F. hum. Genet., 10, 196.

Pendred, V. (1896). Deaf-mutism and goitre. Lancet, 2, 532.

Reed, S. C. (1937). The inheritance and expression of fused, a new mutation in the house mouse. Genetics, 22, 1.

Richards, B. W. (1963). Sex-linked deaf-mutism. Ann. hum. Genet., 26, 195.

Settelmayer, J. R., and Hogan, M. (1961). Waardenburg's syndrome-report of a case in a non-Dutch family. New Engl. $\mathcal{f}$. Med., 246, 500.

Shaw, R. F., and Glover, R. A. (1961). Abnormal segregation in hereditary renal disease with deafness. Amer. F. hum. Genet., 13, 89.

Sidman, M., Ray, B. A., Sidman, R. L., and Klinger, J. M. (1966). Hearing and vision in neurological mutant mice: a method for their evaluation. Exp. Neurol., 16, 377.

Sidman, R. L., Green, M. C., and Appel, S. H. (1965). Catalog of the Neurological Mutants of the Mouse. Harvard University Press, Cambridge, Massachusetts.

Slatis, H. M. (1958). Comments on the inheritance of deafmutism in Northern Ireland. Ann. hum. Genet., 22, 153.

Smith, A. (1939). Unilateral hereditary deafness. Lancet, 2, 1172.

Stein, K. F., and Huber, S. A. (1960). Morphology and behavior of Waltzer-type mice. $\quad$ f. Morph., 106, 197.

- , and Rudin, I. A. (1953). Development of mice homozygous for the gene for looptail. f. Hered., 44, 59.

Steinberg, G. (1937). Erbliche Augenkrankheiten und Ohrenleiden. Z. Hals-, Nas.- u. Ohrenheilk, 42, 320.

Stevenson, A. C., and Cheeseman, E. A. (1956). Hereditary deaf mutism with particular reference to Northern Ireland. Ann. hum. Genet., 20, 177.

Tietz, W. (1963). A syndrome of deaf-mutism associated with albinism showing dominant autosomal inheritance. Amer. $\mathcal{F}$. hum. Genet., 15, 259.

Truslove, G. M. (1956). The anatomy and development of the fidget mouse. $\mathcal{F}$. Genet., 54, 64 . (1962). A gene causing ocular retardation in the mouse. $\mathcal{f}$.
Embryol. exp. Morph., 10, 652 . 
Usher, C. H. (1914). On the inheritance of retinitis pigmentosa, with notes of cases. Roy. Lond. ophthal. Hosp. Rep., 19, 130.

Waardenburg, P. J. (1951). A new syndrome combining developmental anomalies of the eyelids, eyebrows and nose root with pigmentary defects of the iris and head hair and with congenital deafness. Amer. F. hum. Genet., 3, 195.

Waddington, C. H. (1937). The determination of the auditory placode in the chick. F. exp. Biol., 14, 232

Warburg, M. (1961). Norrie's disease. A new hereditary bilateral pseudotumour of the retina. Acta ophthal. (Kbh.), 39, 757.

- (1963). Norrie's disease (atrofia bulborum hereditaria). ibid., 41, 134.

Whalen, R. E., Huang, S., Peschel, E., and McIntosh, H. D. (1961). Hereditary nephropathy, deafness and renal foam cells. Amer. . Med., 31, 171.

Wildervanck, L. S. (1963). Perceptive deafness associated with split-hand and -foot, a new syndrome? Acta genet. (Basel), 13, 161.

Williamson, D. A. J. (1961). Alport's syndrome of heriditary nephritis with deafness. Lancet, 2,1321 .
Woolley, G. W., and Dickie, M. M. (1945). Pirouetting mice. f. Hered., 36, 281.

Yntema, C. L. (1937). An experimental study of the origin of the cells which constitute the VIIth and VIIIth cranial ganglia and nerves in the embryo of Amblystoma punctatum. F. exp. Zool., 75, 75.

- (1950). An analysis of induction of the ear from foreign ectoderm in the salamander embryo. ibid., 113, 211.

Zelig, S. '(1961). Syndrome of Waardenburg with deafness. Laryngoscope (St. Louis), 71, 19.

Zimmermann, K. (1935). Erbliche Gehirnerkrankungen der Hausmaus. Erbarzt (Beil. z. Dtsch. Ärztebl.), 2, 119.

Ziprkowski, L., and Adam, A. (1964). Recessive total albinism and congenital deaf-mutism. Arch. Derm., 89, 151.

-, Krakowski, A., Adam, A., Costeff, H., and Sade, J. (1962). Partial albinism and deafmutism due to a recessive sex-linked gene. ibid., 86, 530.

Zwilling, E. (1941). The determination of the otic vesicle in Rana pipiens. F. exp. Zool., 86, 333. 